\title{
Ediacaran in Uruguay: palaeoclimatic and palaeobiological implications
}

\author{
ERNESTO PECOITS, MURRAY GINGRAS, NATALIE AUBET and KURT KONHAUSER \\ Department of Earth and Atmospheric Sciences, University of Alberta, Edmonton, AB, Canada \\ (E-mail: murray.gingras@gmail.com)
}

\begin{abstract}
The Ediacaran to lowermost Cambrian successions of south-eastern Uruguay preserve an unusual and significant record of deposits generated during the Gondwana assembly ( $c a 590$ to $535 \mathrm{Ma}$ ). This study presents a review of data obtained through extensive field-based mapping coupled with detailed sedimentology and stratigraphy of key formations. The geological units within the study area consist of the Maldonado Group (Playa Hermosa, Las Ventanas and San Carlos formations), the Arroyo del Soldado Group (Yerbal, Polanco Limestones, Barriga Negra and Cerro Espuelitas formations) and the Arroyo de la Pedrera Group (Piedras de Afilar and Cerro Victoria formations). The Maldonado Group is characterized by a glacially influenced volcanogenicsedimentary sequence with ice-rafted debris and dropstones in the Playa Hermosa and Las Ventanas formations. The Arroyo del Soldado Group is a mixed siliciclastic-carbonate succession, mainly represented by an intercalation of basal pink dolostones, banded siltstones, rhythmites of dolostone-limestone, iron formations, cherts and conglomerates. Carbonates in the Polanco Limestones Formation are characterized by a negative $\delta^{13} \mathrm{C}$ excursion up to $-3 \cdot 26 \%$ PeeDeeBelemnite. The Arroyo de la Pedrera Group consists of quartz arenites and stromatolitic/oolitic dolostones. Preliminary data indicate that the Precambrian-Cambrian could be contained within or at the base of this group. The entire succession is almost $6000 \mathrm{~m}$ thick, and contains a rich fossil assemblage composed of organic-walled microfossils and small shelly fauna, including the index fossil Cloudina riemkeae. The stratigraphic and chemostratigraphic features are suggestive of a Gaskier age ( ca $580 \mathrm{Ma}$ ) for the basal glacial-related units. In this scenario, the results show the importance of lithostratigraphic, biostratigraphic and chemostratigraphic data of these Ediacaran units in the global correlation of terminal Proterozoic sedimentary rocks.
\end{abstract}

Keywords Ediacaran, palaeoclimatology, palaeontology, stratigraphy, SW-Gondwana, Uruguay.

\section{INTRODUCTION}

The Neoproterozoic is characterized by extreme environmental changes. The presence of lowlatitude glacial successions, an apparent correlation between banded iron formations (BIF) and glacial events, carbonates deposited during postglacial sea-level rise ('cap carbonates') and negative carbon-isotope excursions of Neoproterozoic sea water are some of the features associated with that time (Harland, 1964; Kirschvink, 1992;
Hoffman et al., 1998a,b; Hoffman \& Schrag, 2000, 2002). Correspondingly, the Neoproterozoic marks a time of significant changes in ocean and atmosphere chemistry. Atmospheric oxygen levels may have approached $18 \%$ of the present atmospheric levels and, along with the concomitant increase in ocean oxygenation, there would have been an attendant deepening of the oxicanoxic interface and decreased sulphide levels owing to increased aerobic respiration (Canfield \& Teske, 1996). Increased levels of oxygen probably 
facilitated the emergence of metazoans as early as ca 600 Ma (Valentine, 2004).

One of the most researched aspects of the Neoproterozoic is the widely distributed glaciogenic deposits, interpreted as resulting from a global glaciation, the so-called 'Snowball Earth' event, in which the world's oceans are hypothesized to have been almost completely covered by continuous sea ice that formed a barrier between the oceans and atmosphere, resulting in severely diminished biological productivity (Hoffman \& Schrag, 2002). The insulation of the ocean from the atmosphere led to ocean-water anoxia, resulting in an increase in the concentration of dissolved Fe(II) and $\mathrm{Mn}(\mathrm{II})$. Then, as the ice melted and ocean circulation became re-established, the metals became oxidized and accumulated as BIF (Kirschvink, 1992; Klein \& Beukes, 1993). Major deposits include the $700 \mathrm{Ma}$ Rapitan Group of the Mackenzie Mountains in Canada and the ironmanganese deposit of the Urucum district in Brazil (Klein \& Beukes, 1993; Klein \& Ladeira, 2004).

A transient but intense greenhouse climate ensued, leading to enhanced weathering of the glacially eroded landscape, increased alkalinity and carbonate precipitation (Hoffman \& Schrag, 2002); this process resulted in the rapid deposition of ${ }^{13} \mathrm{C}$-depleted, finely laminated dolomicrites (cap carbonates) directly on top of the glacial debris. These atypical carbonates generally are composed of dolostone and sharply overlie the glacial deposits, with no evidence of a hiatus in deposition. An interesting feature of these rocks is the C-isotopic composition which, during the Neoproterozoic, is much more variable than that recorded in the Phanerozoic. Once ice covered the oceans, biological productivity would have collapsed producing a drop in ${ }^{13} \mathrm{C}$ content. The most ${ }^{13} \mathrm{C}$ negative ratios, found in cap carbonates, are equivalent to those of mantle carbon (Hoffman \& Schrag, 2002).

What effect global glaciation had on the microbiota is unclear. Certainly, chemotrophic and anaerobically respiring heterotrophic prokaryotes would have survived the polar conditions, but phototrophic bacteria and eukaryotes must have fared worse. In fact, the fossil record suggests that there was a marked decline in palynoflora diversity at the time of the glaciations (Vidal \& Knoll, 1982; Vidal \& Moczydlowska-Vidal, 1997; Walter et al., 2000), but the existence of extant photosynthetic groups known from pre-glacial times indicates that some found refuge, possibly in pockets of open water in the circum-equatorial ocean or around shallow hot springs associated with volcanic islands (Hyde et al., 2000).
Despite the significant changes that appear to have affected the biosphere during the Neoproterozoic, studies of the rock successions are comparatively limited. Very little work has been conducted in South America, despite the presence of well-exposed sedimentary deposits that bracket the glacial events. In particular, Uruguay possesses several kilometres of continuous Neoproterozoic sequences, but the lack of detailed stratigraphic studies has prevented the correlation of these with other post-glacial carbonates around the world. The aim of this investigation was to provide a detailed lithostratigraphic study of a sedimentary succession that includes preglacial and post-glacial events. The age, geological setting and palaeoenvironmental implications in terms of the observed sedimentological features (i.e. BIF, pink dolostones, diamictites and unique carbonate rhythmites) are considered and related to the palaeobiological complexity during this critical period.

\section{LITHOSTRATIGRAPHY, SEDIMENTOLOGY AND PALAEONTOLOGY}

Three major Ediacaran-lowermost Cambrian lithostratigraphic units were recognized and described in eastern Uruguay: the Maldonado, Arroyo del Soldado and Arroyo de la Pedrera groups. The entire succession has a general NNESSW orientation and is $c a 400 \mathrm{~km}$ long and more than $80 \mathrm{~km}$ wide resting on a diverse assemblage of Proterozoic and Archean rocks belonging to the Piedra Alta, Nico Pérez and Cuchilla Dionisio Terranes (Figs. 1A-B and 2).

\section{Maldonado Group}

The Maldonado Group was formally erected by Pecoits et al. (2005a) to include the Playa Hermosa and Las Ventanas formations. The total thickness of the group reaches $c a 1600 \mathrm{~m}$ comprising acidic and basic volcanic rocks, as well as sedimentary deposits (Fig. 2), generated in a tectonically active basin. The complete succession shows brittle and ductile deformation as demonstrated by the presence of fractures, strike-slip faults and folds. The unit lies on an angular unconformity above the ?Mesoproterozoic Lavalleja Group and granitoid rocks of undetermined age. The strata comprising the group originally were described near the towns of Piriápolis and Pan de Azúcar. Subsequent work showed that the sequence continues to 


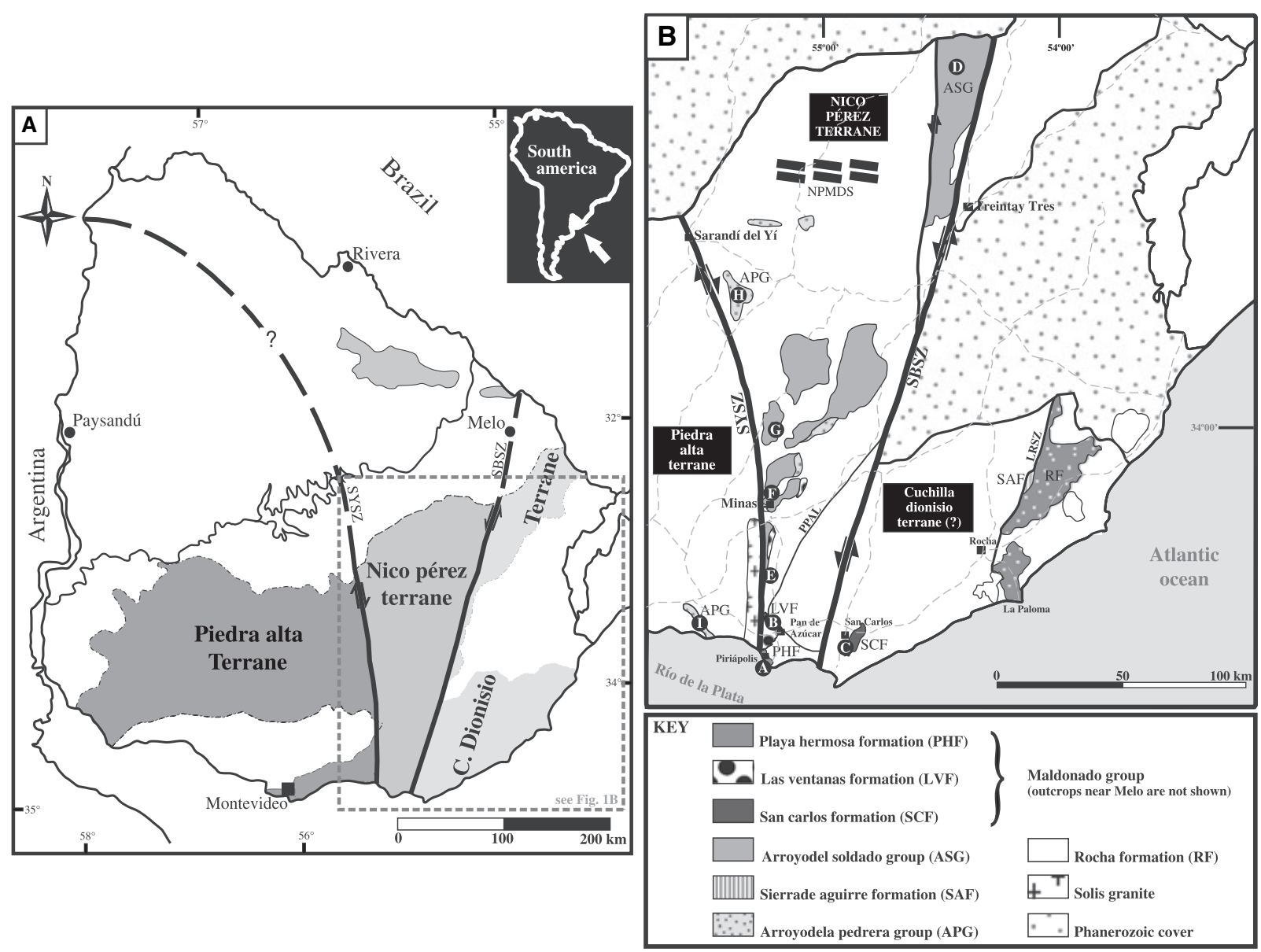

Fig. 1. (A) Tectonostratigraphic subdivision of the Crystalline Basement of Uruguay according to Bossi (2003). SYSZ, Sarandí del Yí Shear Zone; SBSZ, Sierra Ballena Shear Zone. (B) Distribution of the Neoproterozoic-Cambrian sedimentary and volcanosedimentary sequences and location of the profiles discussed in the text (modified from Pecoits et al., 2005a). NPMDS, Nico Pérez Mafic Dyke Swarm; LRSZ, Laguna de Rocha Shear Zone.

the north (Fig. 1B). Outcrops of the Maldonado Group cover an area of $c a 190 \mathrm{~km}^{2}$.

\section{Playa Hermosa Formation}

Masquelin \& Sánchez (1993) conducted the first detailed work on the sedimentological and tectonic features of the Playa Hermosa Formation. However, this succession was previously identified by Preciozzi et al. (1989) to include folded and intruded sedimentary rocks cropping out along the south-eastern coast of Uruguay from Playa Verde to Playa Grande (Fig. 1B). Pazos et al. (2003) described the lower section of this unit and recognized two distinctive facies associations: (i) primarily medium to coarse-grained; and (ii) dominantly fine-grained units. The coarsegrained units consist of interbedded breccias, conglomerates, sandstones and minor mudstones that occur at the base and top of the succession; they were taken to show depositional conditions of slope instability and high rates of sedimenta- tion (interpreted as being proximal to source). The second facies association mainly is composed of diamictites, rhythmites, sandstones and mudstones, which are interpreted to have been deposited in a distal glacially influenced environment. Both facies associations accumulated in a sub-aqueous marine environment and represent a proximal to distal depositional trend. Evidence for the glacial nature of the Playa Hermosa Formation includes dropstones, rhythmites and ice-rafted diamictites. Pazos et al. (2003) contended that this glacial-related succession constituted a record of the Varanger glaciation at the Río de la Plata Craton. The attribution of this unit to the Ediacaran is based on Masquelin \& Sánchez (1993) who recognized chilled margins between the sedimentary strata and trachytic dykes. These hypabyssal rocks, which are part of the Sierra de las Animas Complex (Oyhantçabal et al., 1993), have produced $\mathrm{Rb} / \mathrm{Sr}$ and $\mathrm{K} / \mathrm{Ar}$ ages between 615 and 500 Ma (Bossi et al., 1993; Sánchez \& 


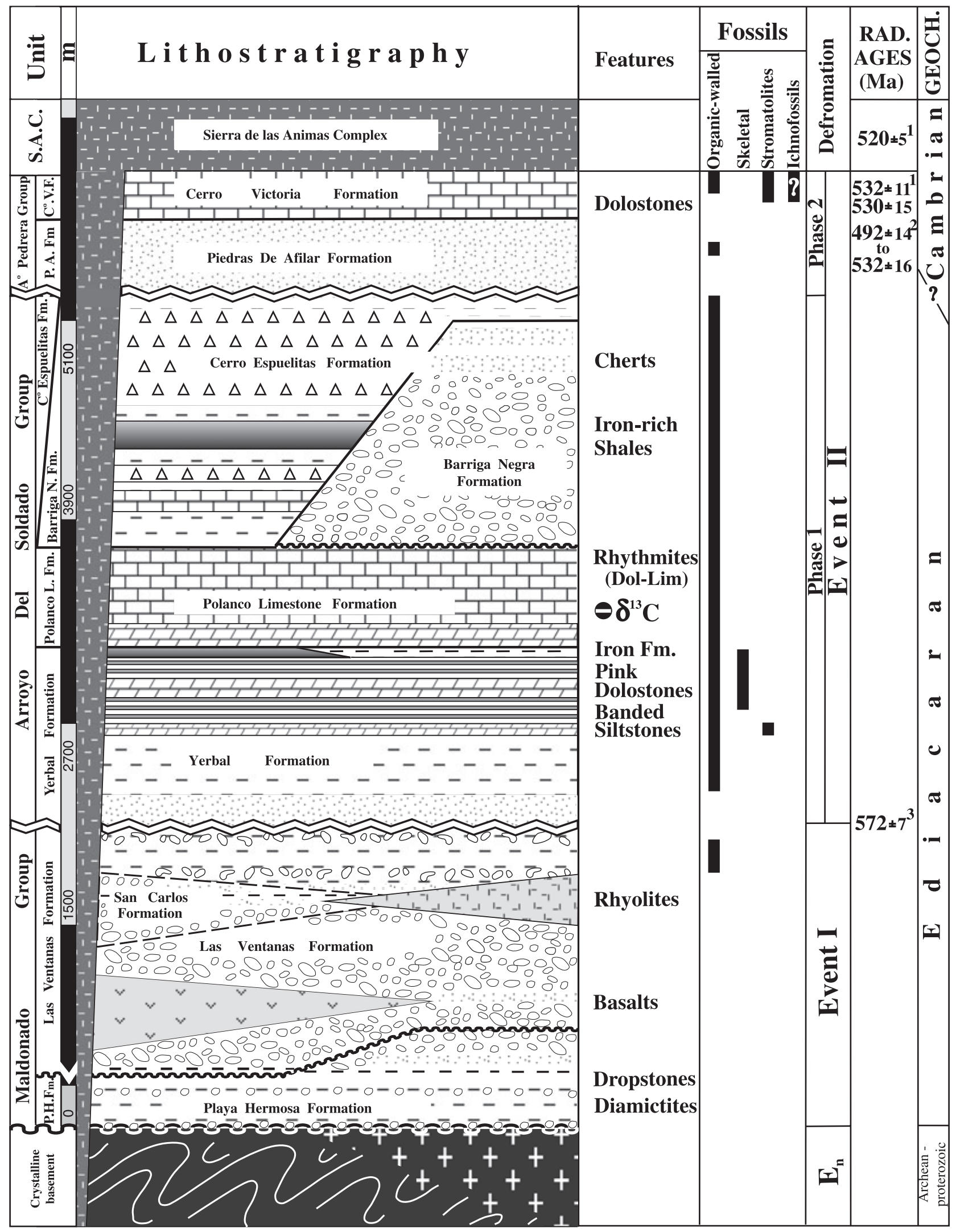

Fig. 2. Overall lithostratigraphic cross-section showing some key lithological, palaeontological, structural and radiometric age features of Ediacaran-Cambrian units studied in Uruguay (Radiometric ages: 1 intrusive granitoids; 2 recrystallization of clayminerals in shales; 3 synkinematic muscovite in thrust) (see text for explanation). 
Fig. 3. Stratigraphic column of the stratotype of the Playa Hermosa Formation (point A, Fig. 1B; Playa Verde, Piriápolis). $\mathrm{m}$

Colour

Cl Si $\mathrm{s}_{\mathrm{vf}} \mathrm{s}_{\mathrm{f}} \mathrm{s}_{\mathrm{m}} \mathrm{s}_{\mathrm{c}} \mathrm{s}_{\mathrm{ve}} \quad \mathrm{Co}$

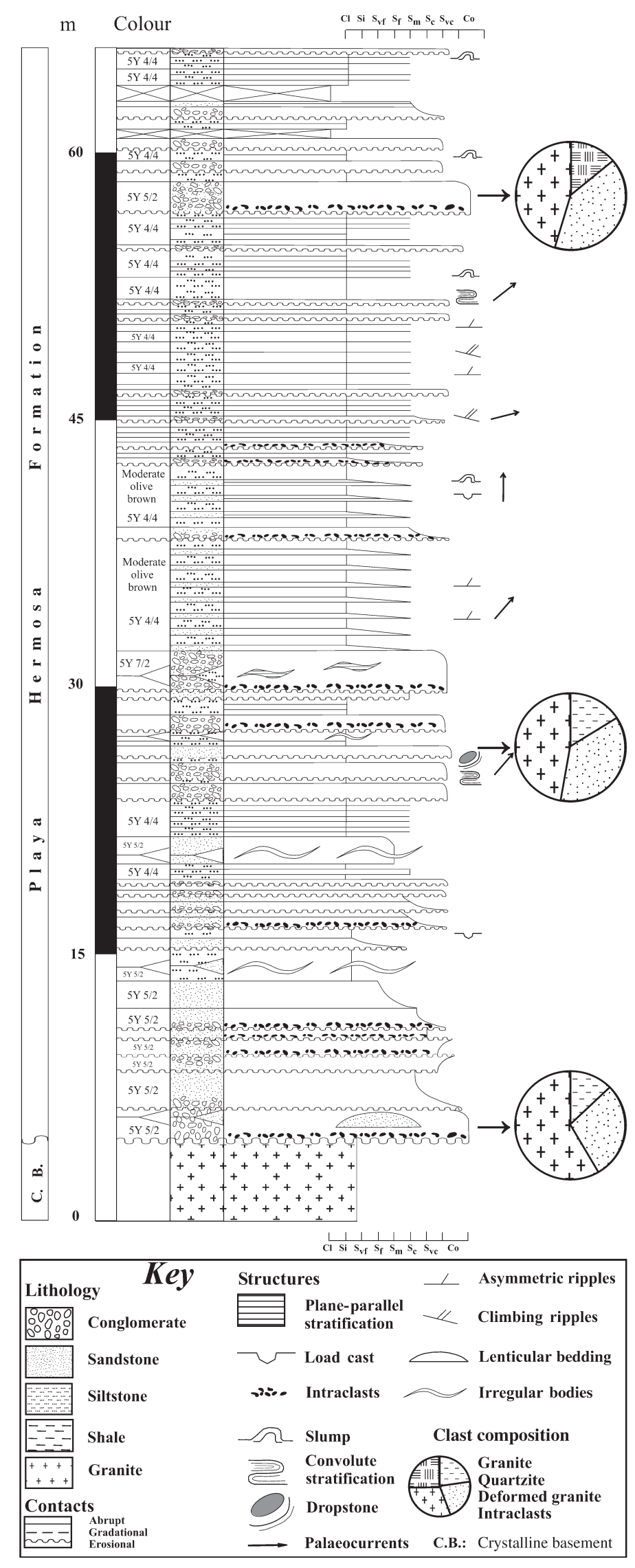

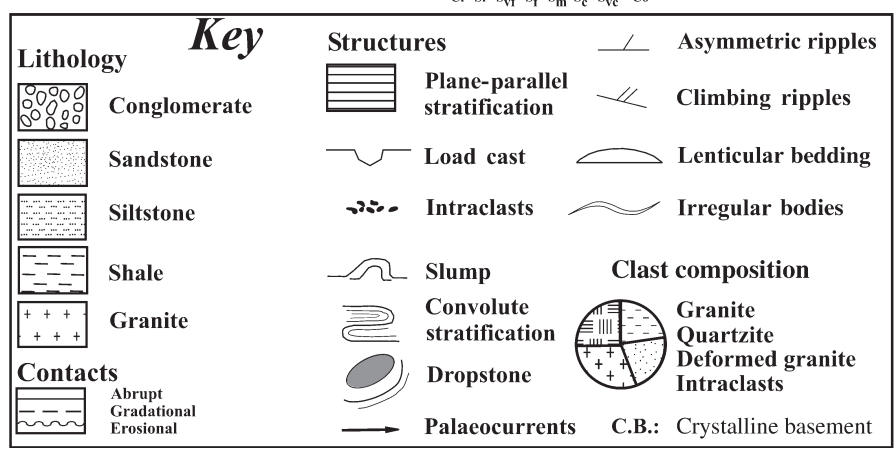

(c) 2007 The Authors. Journal compilation @ 2007 International Association of Sedimentologists, Sedimentology, 55, 689-719 
Linares, 1996). Preliminary palaeomagnetic data obtained from the Playa Hermosa Formation suggest low palaeo-latitudes during the sedimentation (Sánchez \& Rapalini, 2002).

The Playa Hermosa Formation unconformably overlies a pink leucocratic granite of unknown age (Fig. 3). The contact is demarcated by a clastsupported conglomerate composed of leucocratic granite $(60 \%)$, quartzite $(25 \%)$ and pelitic intraclasts $(15 \%)$. Up-section, the conglomerates occur as irregular to lenticular bodies within sandstone beds or (more rarely) may grade laterally into sandstone. In the middle and upper part of the section, thin, erosionally based conglomerate beds commonly contain intraclasts. Conglomerates, similar to those appearing at the base, are present at the top of the Playa Hermosa Formation; these are composed of leucocratic granite $(45 \%)$, quartzite $(40 \%)$ and pelitic intraclasts (15\%). Matrix-supported conglomerates occur almost exclusively in the middle of the succession although some thin beds are observed up-section. Therein, $5 \mathrm{~m}$ thick pebble-diamictite and rare thin-bedded turbidites are present.

The basal conglomerates are interpreted as a product of sediment gravity flows (grain flow and debris flow deposits). The top of the beds are either amalgamated with subsequent flow deposits or grade into overlying turbidites forming a compound debrite-turbidite couplet (Einsele, 2000). The diamictites (located up-section) are dominated by ice-rafted debris. The absence of grain-size segregation and the presence of chatter marks on pebbles strongly reinforce a glacial interpretation (Pazos et al., 2003).

The lower sandstones are both interbedded with the conglomerates, and occur as lenticular beds. These lithologies appear also up-section as lenticular bedding, irregular bodies and massive beds within thicker pelitic beds. The sandstones commonly occur as millimetre to centimetre scale sandstone/siltstone intercalations (Fig. 3). Coarser-grained beds are thicker. These deposits are interpreted as turbidites. In the middle part of the unit, as much as $10 \mathrm{~m}$ of medium to coarsegrained sandstones interbedded with siltstones are observed. Up-section the bedding thickness and grain-size are reduced and climbing ripples become common. The uppermost beds show planar parallel lamination composed of coarse and fine-grained siltstone; this feature represents a thinning and fining-upward trend from more proximal to distal turbidites (Bouma $\mathrm{T}_{\mathrm{b}-\mathrm{e}}-\mathrm{T}_{\mathrm{d}-\mathrm{e}}$ ).

The Playa Hermosa Formation records deposition in a tectonically active, extensional basin.
Deformational and palaeocurrent structures suggest sediment transport towards N-NNE. Pazos et al. (2003) referred to dropstones, ice-rafted debris, rhythmites and a striated boulder as evidence of a glacial origin for the succession. Given that the rhythmites are interpreted as distal turbidites herein and striated or faceted clasts were not documented, ice-rafted diamictites and dropstones constitute the best evidence of a glaciogenic origin (Fig. 4A). It is most likely that the described lithofacies represent the record of distal subaqueous outwash deposits. Considering the lack of lodgement, ice-contact deposits and proximal outwash deposits, a (maximum) proglacial zone of deposition is suggested (see Edwards, 1986).

\section{Las Ventanas Formation}

Midot (1984) erected the Las Ventanas Formation to include conglomerates, sandstones and pelites cropping out at Las Ventanas hill and in the surrounding areas. This unit was considered by Midot (1984) and various other authors as an Ordovician sedimentary sequence (Preciozzi et al., 1988; Bossi \& Navarro, 1991; Masquelin \& Sánchez, 1993; Bossi et al., 1998; Pazos et al., 2003). This assumption was founded mainly on the supposed development of alluvial fans sourced from the Sierra de las Ánimas Complex (Cambrian), located towards the west.

Recently, mapping and sedimentological and stratigraphical studies of the Las Ventanas Formation carried by Pecoits (2002), led to a redefinition of the unit as a Neoproterozoic volcano-sedimentary sequence. Therein, one proximal and one distal facies association can be recognized (Pecoits, 2002). The first facies association is composed of clast-supported conglomerates, diamictites and massive sandstones. The second facies contains laminated siltstones and sandstone-pelite rhythmites with rare sandstones and conglomerates (Pecoits, 2003a). These deposits were interpreted as a product of sheetflood-dominated fan deltas intercalated with minor marine deposits. Pecoits et al. (2005a) reported evidence of glacial influence in the lower part of the unit, where foliated outsized clasts of volcanic rocks in sedimentary rhythmite layers were documented.

To the south of the mapped area intercalated basalts, acidic volcanoclastic rocks and rhyolites are recognized. This bimodal volcanism was thought to represent part of the Sierra de las Ánimas Complex (see for example Sánchez \& Rapalini, 2002 and references therein). However, based on detailed geological mapping of the Las 
Ventanas Formation it is likely that this unit was influenced by the Puntas del Pan de Azúcar Lineament (Fig. 5). Near this fault, which is located to the east of the study area, the sequence shows intense deformation; this deformation suggests that the deposition of the Las Ventanas Formation occurred before the last reactivation of the lineament, which was dated at $572 \pm 7 \mathrm{Ma}$ (K/Ar) (Bossi \& Campal, 1992). Furthermore, the late-orogenic Pan de Azúcar Granite, which intrudes the Las Ventanas Formation (Pecoits, $2003 \mathrm{~b}$ ), was dated at $559 \pm 28 \mathrm{Ma}(\mathrm{Rb} / \mathrm{Sr}$ ) (Preciozzi et al., 1993). Also, the trachytes and syenites of the Sierra de Las Ánimas Complex intrude the unit and yield an age of $520 \pm 5 \mathrm{Ma}(\mathrm{Rb} / \mathrm{Sr})$ (Bossi et al., 1993). Finally, the occurrence of microfossils such as Bavlinella faveolata Schepeleva (Vidal, 1976) in shales has been reported by Pecoits (2003a). Although this taxon possesses a long stratigraphic range (Upper Riphean to Ordovician; see, for example Mansuy \& Vidal, 1983; Knoll \& Sweet, 1985), its acme in the Ediacaran and its occurrence in the Arroyo del Soldado Group has stratigraphic and environmental significance (see Discussion).

The section exposed in the northern part of the type area is designated herein as the stratoype of the Las Ventanas Formation. At this locale $1200 \mathrm{~m}$ of Las Ventanas strata are exposed continuously (Fig. 6). The unit lies unconformably on the Lavalleja Group but the contact is not exposed at this section. The unit begins with a $690 \mathrm{~m}$ thick fining-upward and thinning-upward cycle. Conglomerates, sandstones and siltstones dominate the lowermost, medial and uppermost sub-cycles respectively. The conglomerates are typically clast-supported and are composed of granite clasts. Arkosic sandstones are present at the top of each sub-cycle. The following changes occur up-section within the lower cycle: (i) bed thickness progressively decreases, from metre-scale to a few millimetres (laminae); (ii) average grain-size decreases from pebbles to silt; (iii) the proportion of granitic clasts also becomes smaller; and (iv) planar parallel stratification and lamination become a common feature in the siltstones but are absent in the lower and medium part of the cycle.

The formation passes up-section into a second cycle almost $560 \mathrm{~m}$ thick, which is composed of minor cycles of sandstones and conglomerates (Fig. 6). The sandstones have a tabular geometry, are massive-appearing and possess non-erosive basal contacts. The conglomerates are clast-supported, polymictic and have a modal grain-size of $3 \mathrm{~cm}$. In the uppermost conglomerate bed the clast-size approaches $10 \mathrm{~cm}$. The clast composition is variable ( $32 \%$ rhyolite, $22 \%$ granite, $12 \%$ quartz, $11 \%$ basic volcanic rocks, $10 \%$ alkaline feldspar, $8 \%$ plagioclase feldspar, $5 \%$ schists). Although uncommon, thin interbedded beds of red and grey pelites also occur.

The unconformable contact of the Las Ventanas Formation to the metamorphic basement (Lavalleja Group) is exposed $100 \mathrm{~m}$ to the south of the mapped area (close to Nueva Carrara Quarry and Apolonia Mine: Fig. 7). At this locale, laminated siltstones contain clasts and impact structures that deform the planar-parallel stratification; these are interpreted as dropstones (Pecoits et al., 2005a; Fig. 4B).

\section{San Carlos Formation}

The San Carlos Formation was erected by Masquelin (1990). The unit is well-developed in the Cuchilla Dionisio Terrane near San Carlos (Fig. 1B). According to previous authors, the unit consists of conglomerates, sandstones and pelites. The San Carlos Formation probably represents a lacustrine or fluvio-lacustrine setting. Sánchez (1998) described trough cross-stratification in sandstone beds indicating palaeocurrents towards the NE and proposed that the San Carlos represents a meandering fluvial depositional system of Ordovician age.

The stratotype of the formation is located $6 \mathrm{~km}$ to the south of San Carlos town where $220 \mathrm{~m}$ of the formation are exposed (base and top not visible) (Fig. 8). The succession is composed of interbedded conglomerates, sandstones and pelites, with the latter dominating up-section. The San Carlos Formation is initiated with 120 m clast-supported conglomerates with a maximum clast size of $1.5 \mathrm{~cm}$. Cycles of 0.5 to $0.8 \mathrm{~m}$ thick centimetrescale pelite and sandstone beds comprise the stratum. Up-section, conglomerate clasts reach $30 \mathrm{~cm}$ in diameter. The coarser conglomerates persist up-section passing upwards into $70 \mathrm{~m}$ of pelite-free conglomerates with minor sandstones.

The sedimentary facies of the San Carlos Formation are similar to those of the middle Las Ventanas Formation (compare Figs 6 and 8). Preliminary palynological macerations carried out in the pelites (Pecoits et al., 2005a) revealed the occurrence of a microbiota similar to that described for the Las Ventanas Formation (Pecoits, 2003a); mainly present are spheroid vesicles of Bavlinella faveolata Schepeleva (Vidal, 1976).

New fieldwork in the area has revealed interbedded rhyolites within the San Carlos Formation. Neither geochronological nor geochemical 

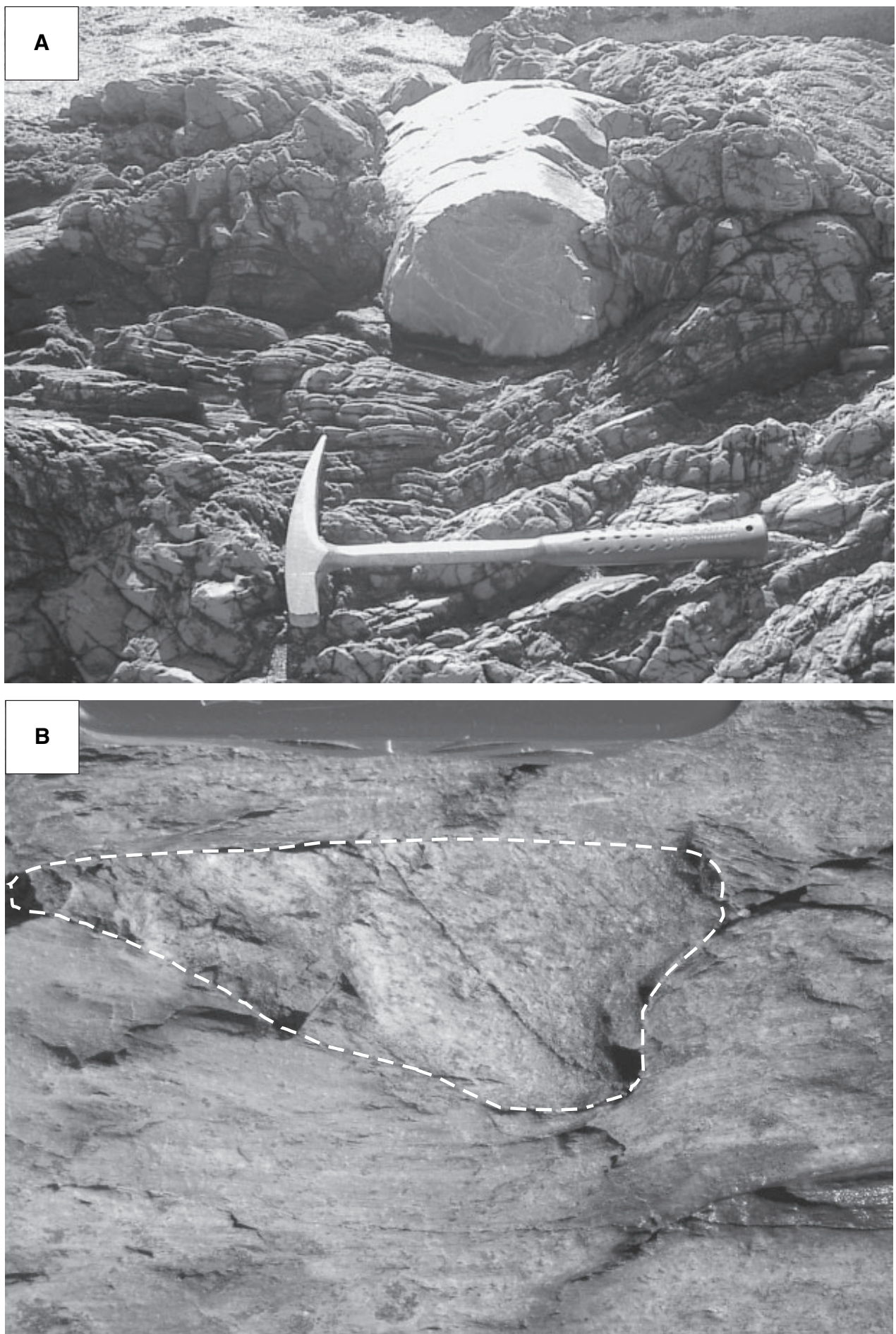

Fig. 4. (A) Quartzitic dropstone block within the mudstones of the Playa Hermosa Formation (length of hammer: $40 \mathrm{~cm}$ ). (B) Laminated siltstones facies from the lower Las Ventanas Formation containing dropstones of basaltic composition (knife: $9 \mathrm{~cm}$ ).

data are available from the rhyolites yet. However, it is plausible that these rocks, as in the case of the Las Ventanas Formation, are related to syn-tectonic to late-tectonic granites. The ages obtained for those granites range between 570 and
590 Ma (Umpierre \& Halpern, 1971; Preciozzi et al., 1993; Basei et al., 2000).

The above characteristics permit correlation of the San Carlos and Las Ventanas Formations. Further research will be required to determine

(C) 2007 The Authors. Journal compilation ㄷ 2007 International Association of Sedimentologists, Sedimentology, 55, 689-719 

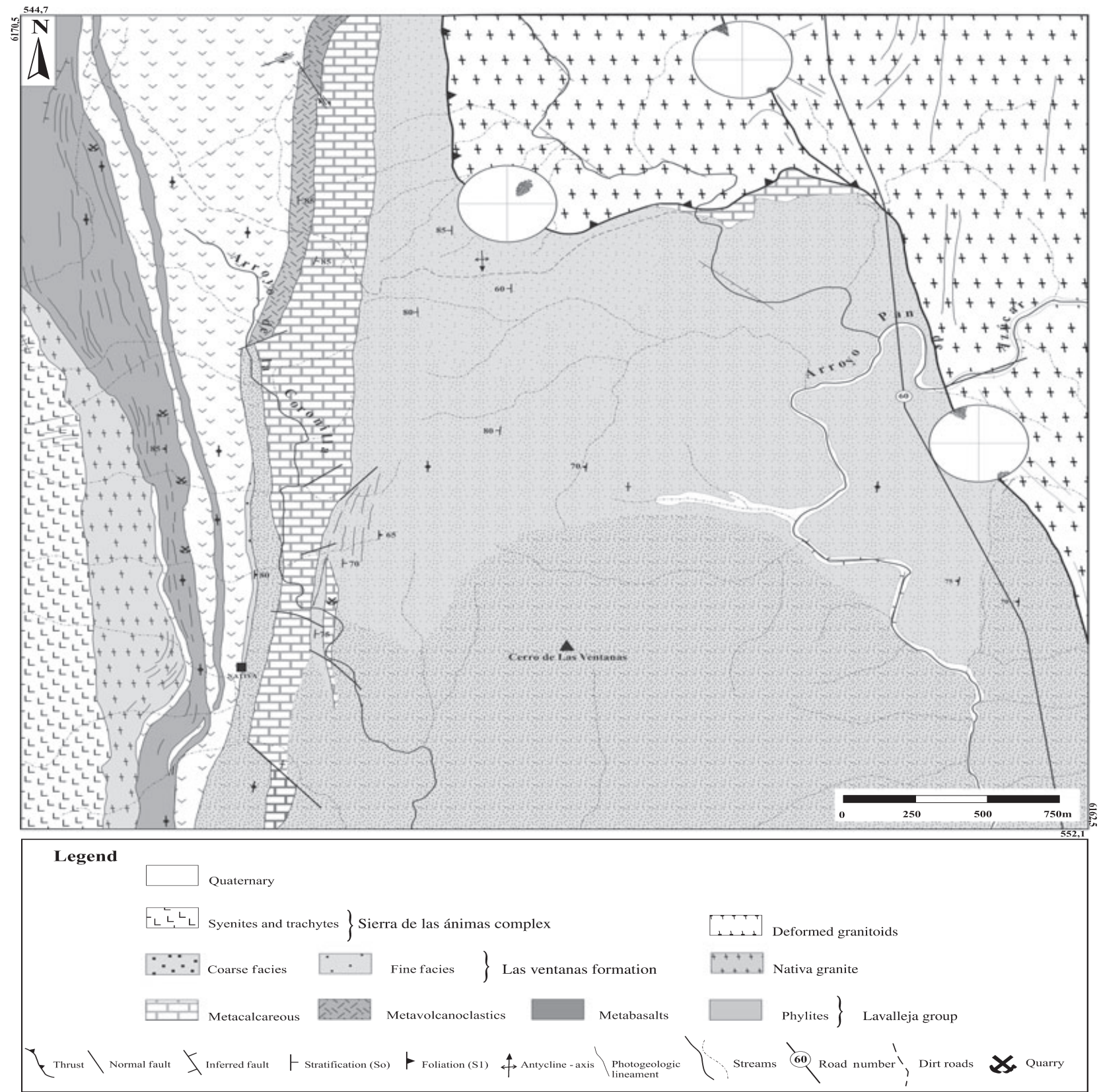

Fig. 5. Geological map of the type area of the Las Ventanas Formation (modified from Pecoits, 2003a). Note the differences in the stretching lineation measured along the major lineament demonstrating a strike-slip reactivation of an older southwestward thrust, which is associated with folds showing southward vergence.

whether both units were deposited in the same basin and subsequently dismantled by the displacement of the Sierra Ballena Shear Zone. The authors suggest that the San Carlos Formation is a volcano-sedimentary unit of Ediacaran age.

\section{Arroyo del Soldado Group}

This lithostratigraphic unit was defined by Gaucher et al. (1996), to include a marine shallowingupward sequence ( $c$ a $1500 \mathrm{~m}$ ) comprising (from base to top) the Polanco Limestone (Goñi \& Hoffstetter, 1964), Cerro Espuelitas, Cerros San Francisco (Montaña \& Sprechmann, 1993) and Cerro Victoria Formations (Montaña \& Sprechmann, 1993). Later, Gaucher et al. (1998) included the basal Yerbal Formation and the Barriga Negra Formation (Midot, 1984), totalling more than $5000 \mathrm{~m}$ in thickness for the entire group. Gaucher et al. (1996) suggested that the succession was deposited on a stable continental shelf undergoing tectonic quiescence. 


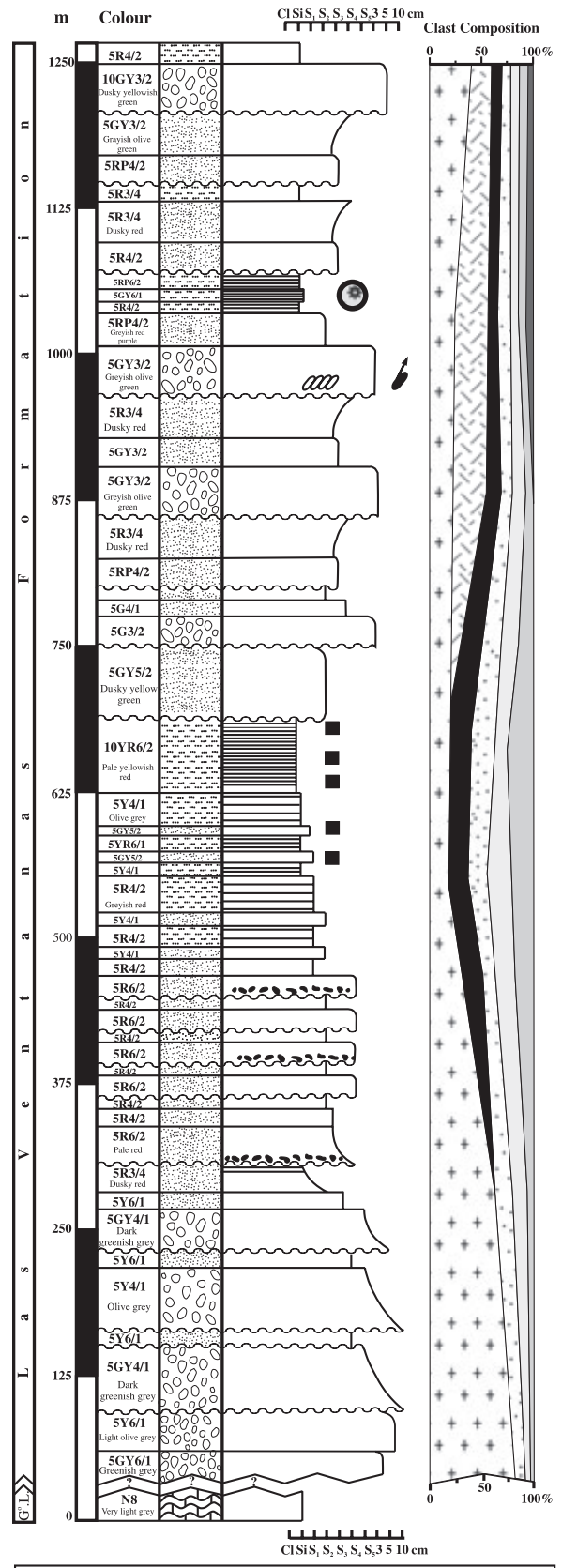

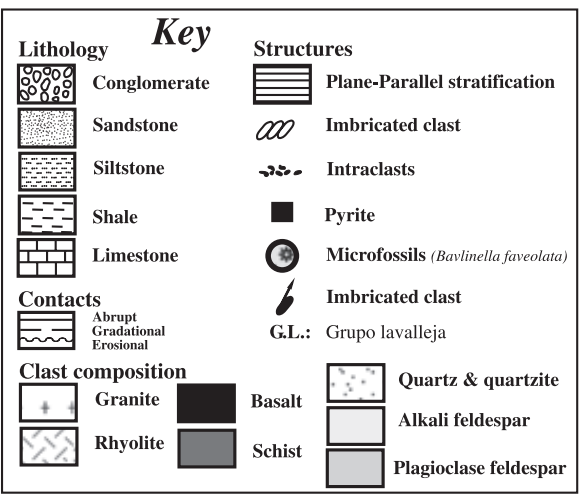

Fig. 6. Stratigraphic column of the Las Ventanas Formation at its stratotype (point B, Fig. 1B).
The age of the group is constrained by radiochronology and biostratigraphic data (Fig. 2). Intrusive syenites and granitoids produced contact metamorphism with ages ranging between 540 and $510 \mathrm{Ma}$. The characteristics of the organic-walled microfauna and the occurrence of the index late Vendian fossil Cloudina riemkeae (Germs, 1972) have suggested a date for the succession as uppermost Vendian (Valdaian) to lowermost Cambrian.

Due to the distinctive features attributed to the Yerbal and Cerro Espuelitas Formations [i.e. distinctive fossils, pink dolostones and iron formations (IF), among others], the following specifically describes stratigraphic profiles emphasizing those characteristics as they can provide constraints on the palaeoclimatological and palaeoenvironmental conditions.

\section{Yerbal Formation}

This stratotype is located along the path parallel to the Arroyo Yerbal Chico where the unit reaches $1500 \mathrm{~m}$ (location D; Fig. 1B). There the transition towards the concordantly overlying Polanco Formation is well-exposed; however, the base is exposed only to the south of Rivera (Fig. 1A), along the Arroyo San Pablo, where the profile has been designated as parastratotype (Gaucher, 2000). According to Gaucher et al. (1998), two different facies associations, shallow-water and deep-water, are present. The shallow-water facies association is the most widely distributed and it consists of basal conglomerates, followed by intercalations of sandstones and pelites in the middle of the succession, grading to banded siltstones at the top. The deep-water facies association comprises an alternation of finely laminated dark shales and arkoses; these represent turbidites. More recently Gaucher et al. (2004) reported the presence of oxide-facies BIF with up to $24 \%$ magnetite/hematite. The BIF reaches a thickness of $50 \mathrm{~m}$. It is likely that the Yerbal Formation records the transgression of the Vendian sea displaying a fining and thinning-upward trend. Organic-walled microfossils and a distinct shelly fauna occur at the top of the formation. The fossils include Cloudina riemkeae (Germs, 1972), Titanotheca coimbrae, Waltheria marburgensis, Soldadotubulus siderophoba and Palaeodiscus mendezalzolai (Gaucher \& Sprechmann, 1999).

In the areas of Minas town and La Salvaje farm, the following sedimentary deposits (in order of decreasing abundance) have been observed: (i) pelites; (ii) sandstones; (iii) carbonates; (iv) IF and cherts. 


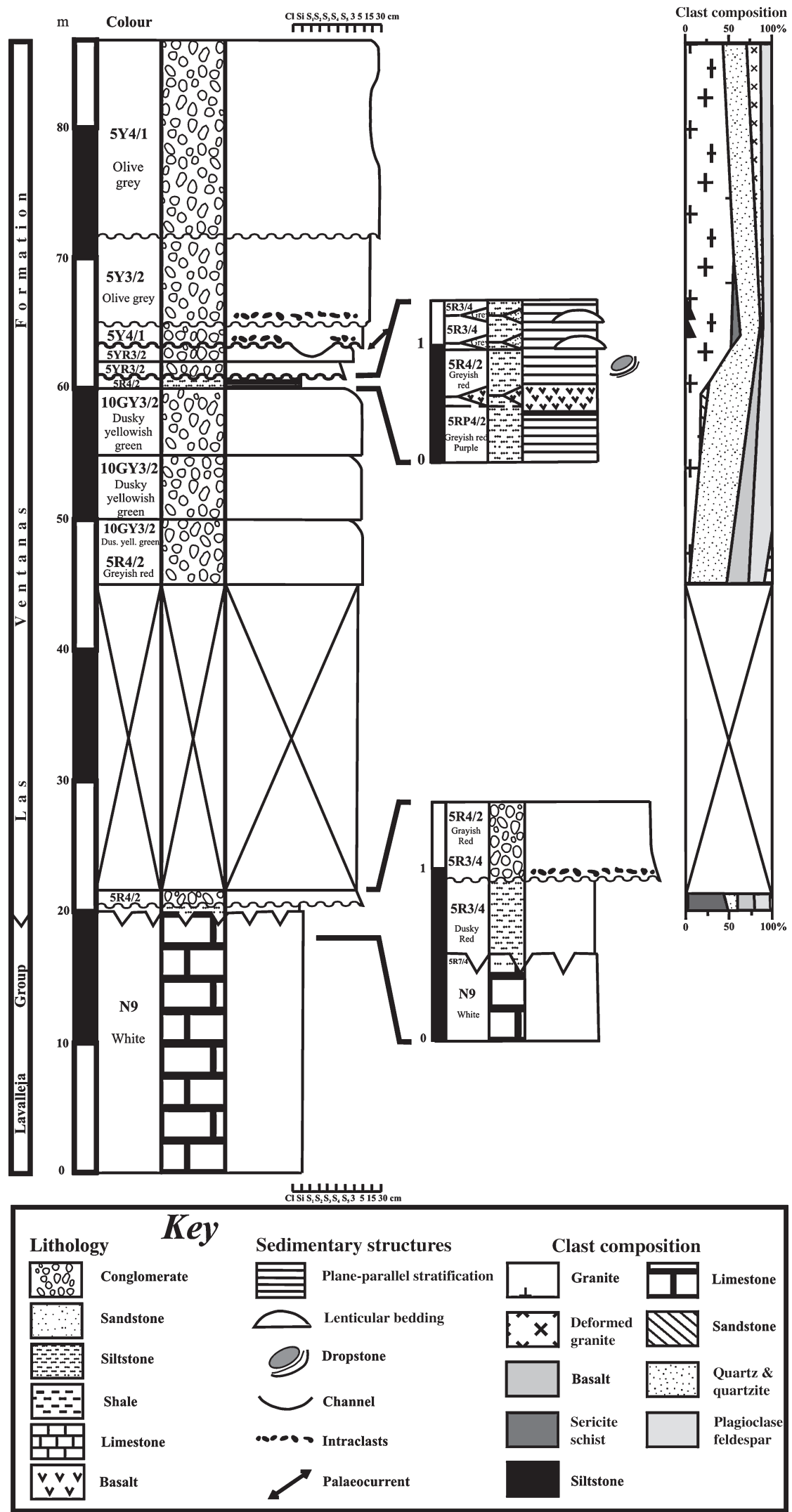

Fig. 7. Stratigraphic section for the lower Las Ventanas Formation at its parastratotype $(8 \cdot 5 \mathrm{~km}$ south of point B, Fig. 1B). 


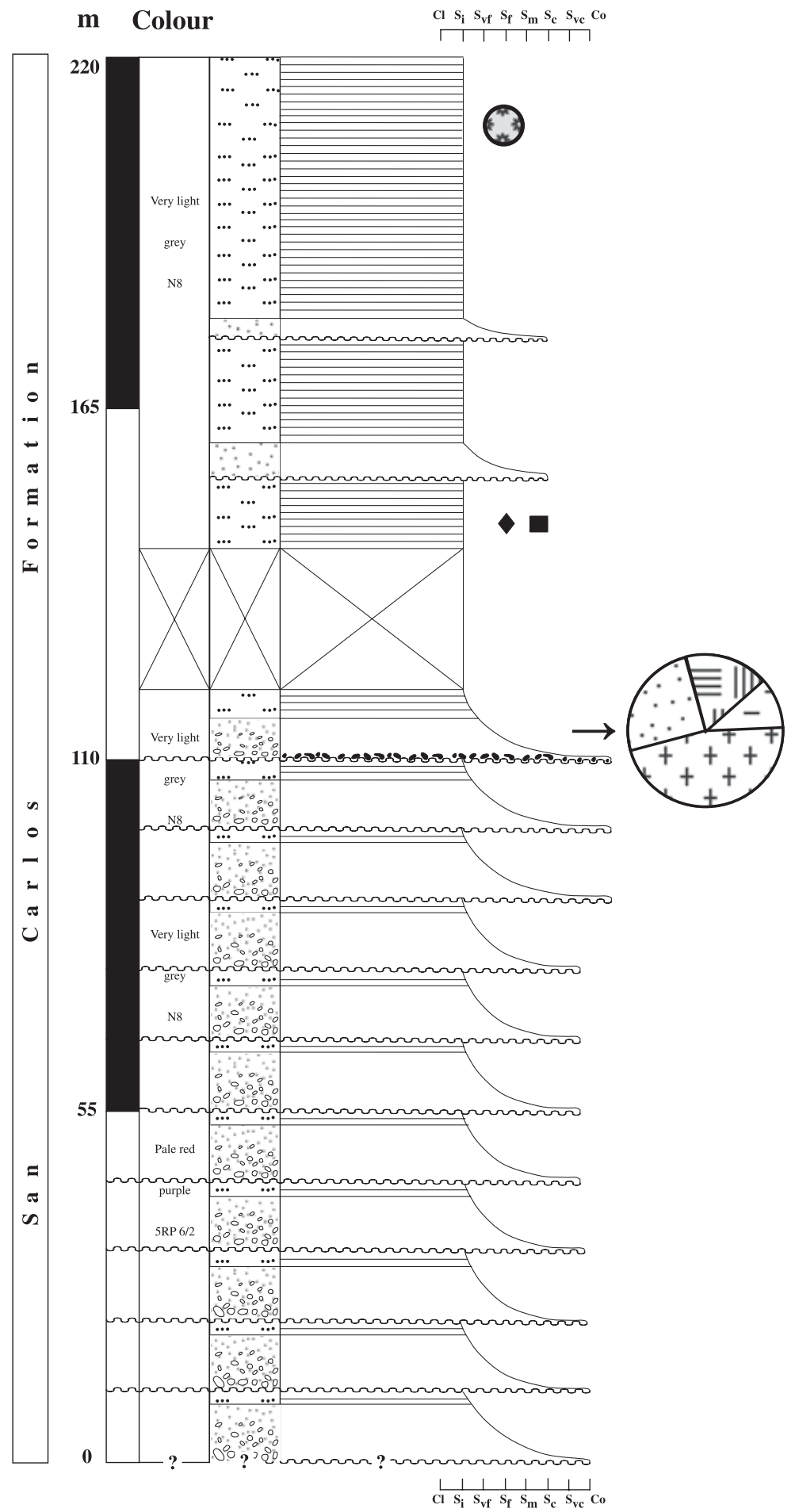

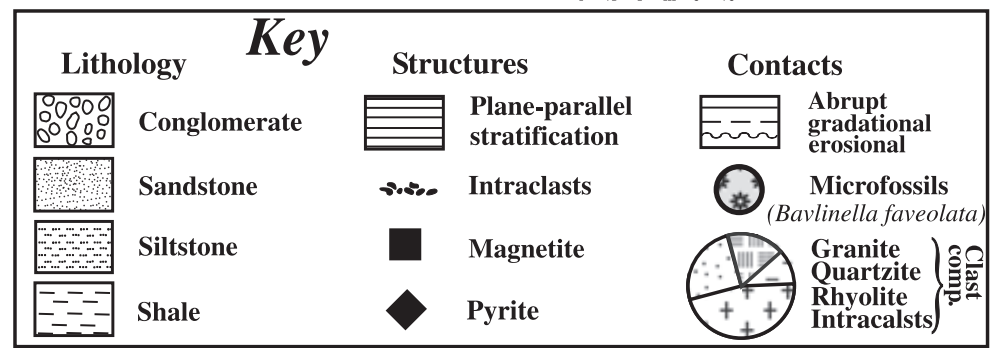

Fig. 8. Simplified stratigraphic column of the San Carlos Formation at its stratotype, $6 \mathrm{~km} \mathrm{SE}$ of San Carlos town (point C, Fig. 1B). 
(i) Siltstones represent the most common lithotype of the Yerbal Formation. At La Salvaje farm they occur in the lowermost and middle parts of the section (Fig. 9). The former consist of dark banded siltstones with rare thin iron-rich bands. Siltstones showing regular microbanding and mesobanding also occur. The rhythmic banding emphasizes the organic-matter content (Fig. 11A). Near the top, large quantities of vase-shaped skeletal fossils of undetermined affinity have been discovered. Preliminary observations suggest that these minute calcareous cones belong to the metazoan Cloudina. Similar siltstones are present close to Minas town where rhythmically laminated and banded siltstones are observed in several outcrops (Figs 10 and 12). Siltstones interbedded with sandstones are common downsection and millimetre to centimetre alternations of iron-rich, carbonate-rich and organic matter-rich dark bands are present in the upper part (Fig. 12B to D).

(ii) In the Minas area, resting on granites of unknown age, the unit is composed of alternating sandstones, pelites and carbonates (Fig. 12A). The basal sandstones are sub-arkosic evolving upwards to orthoquartzites. The sandstones contain ripple cross-stratification and lenticular bedding; near the base they are intercalated with pelites defining fining-upward and thinningupward cycles. Up-section there is a gradational occurrence of white, laminated carbonates. Sandstones underlying the banded siltstones described above are interbedded with pelites at the base and top of the section (Fig. 12B). Some of the beds correspond to volcaniclastic sandstones, which constitute the first report of synsedimentary volcanism for the Arroyo del Soldado Group. Underlying the fossiliferous banded siltstones are $80 \mathrm{~m}$ of intercalated siltstones and arkoses.

(iii) Limestones and dolostones are described for calcareous units. The former occur near the base of the unit where the limestone reaches $45 \mathrm{~m}$ thick and is dominated by parallel bedding and spaced laterally linked hemispheroid stromatolites (Fig. 11B; Logan et al., 1964). Upwards, pink carbonates are followed by calcisiltites and then typical banded siltstones of the unit (Fig. 12A). The dolostones observed up-section consist of $50 \mathrm{~m}$ thick greyish pink dolostones and $75 \mathrm{~m}$ thick pink dolostones, which are finely laminated and resemble cryptalgal laminites. The relationship between the basal stromatolitic carbonates and the overlying pinkish dolostones is not yet resolved, the dolostones are unequivocally interbedded with siltstones and sandstones of the Yerbal Formation. At La Salvaje farm (location E;
Fig. 1B), a $45 \mathrm{~m}$ thick interstratified unit of limestones, dolostones and light grey chert is observed near the base (Fig. 9). Similarly in the overlying Polanco Limestone Formation, finegrained, grey rhythmic alternations of limestone and primary dolostone with rare chert laminae occur and constitute the most common facies of the mentioned unit (Fig. 11C).

(iv) Only two localities are known where these facies occur: La Salvaje farm and east of Minas town. The cherts display different characteristics depending on their stratigraphic position; those interbedded with dolostones and limestones are centimetre-thick greyish white beds (Fig. 9). Up-section the cherts develop into their maximum thickness $(30 \mathrm{~m})$ with bedded greyish green cherts at the base and very finely laminated black and white chert at the top. The latter is rich in organic-walled microfossils. On the uppermost part of the chert beds Fe-enrichment occurs. Elsewhere in the same section (at the base and top of the banded siltstones facies) thin, black, iron-rich chert beds are also present. Banded iron formations are developed at the top of the section located $5 \mathrm{~km}$ east of Minas (Fig. 11D); they can reach $10 \mathrm{~m}$ in thickness, and consist of alternating bands of magnetite/hematite and chert. Stratification is variable but always thinner at the base. It is important to note that the BIF is conformable with the overlying thick-banded siltstone succession suggesting a trend of similar palaeoenvironmental conditions of sedimentation (Fig. 12D).

\section{Cerro Espuelitas Formation}

The stratotype of the Cerro Espuelitas Formation is located in the Cerro Espuelitas, $40 \mathrm{~km}$ north of Minas, where the base of the unit is exposed (location G; Fig. 1B). The geological map of this area, as well as the stratigraphic column, was established by Gaucher (2000). Later detailed mapping has recognized intense local folding, which is responsible for previous overestimations in the thickness of the succession.

The logged section shows the Cerro Espuelitas Formation concordantly overlying the Polanco Formation; the latter consists of alternating stratified dolostones and laminated cherts, with a thickness of $<70 \mathrm{~m}$ (Fig. 13). The top of the unit has not been observed, so the total thickness is unknown. The Cerro Espuelitas Formation is composed of $35 \mathrm{~m}$ of pelitic facies with minor cherts at the base; these grade into $110 \mathrm{~m}$ of thick-bedded cherts. At the top thickly laminated iron-rich and organic-rich shales are present. A distinctive microflora is present in the shales 


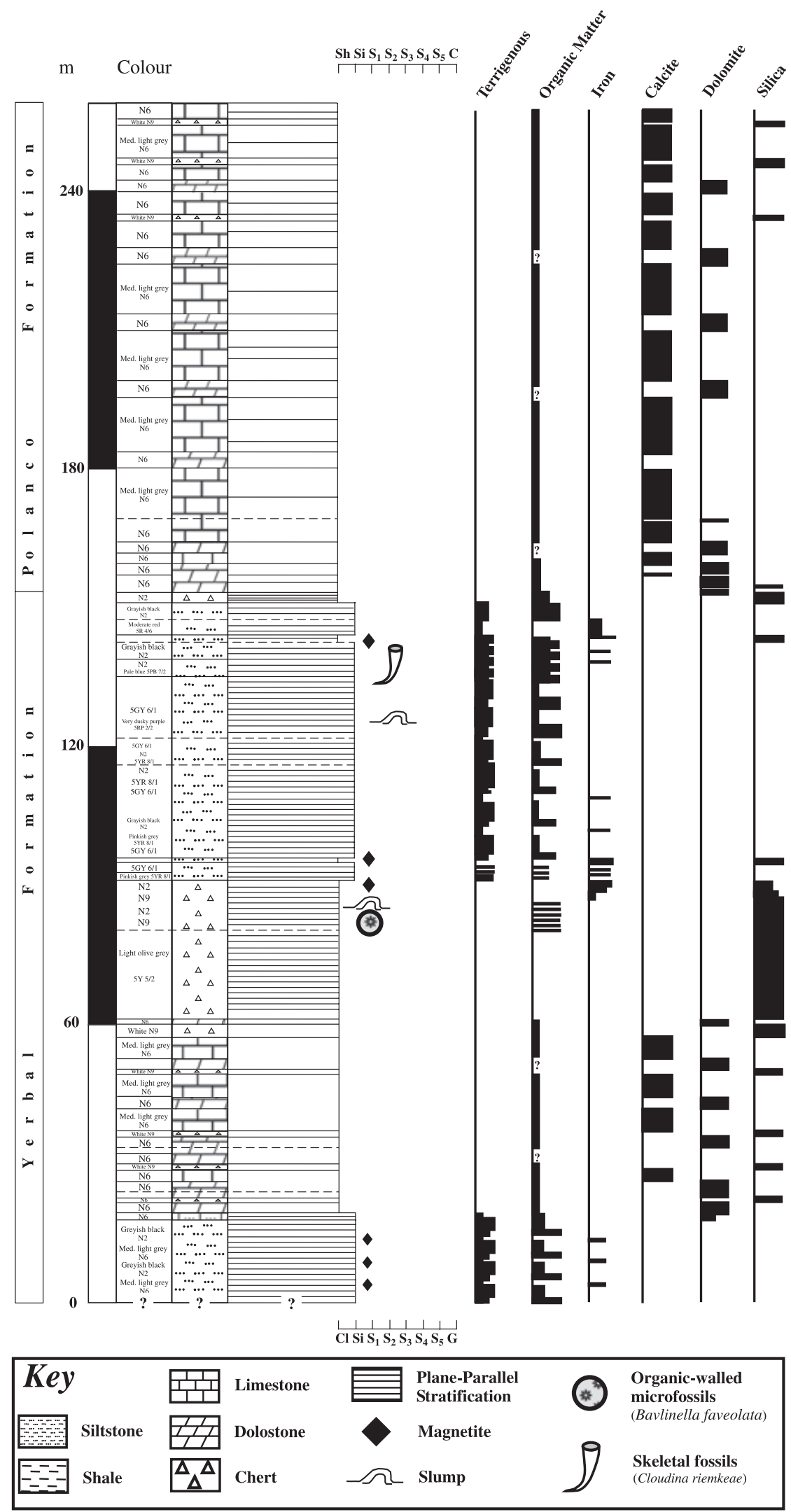

Fig. 9. Logged section of the upper Yerbal and lower Polanco Formations at La Salvaje farm (point E, Fig. 1B). Siliciclastic, organic matter, iron, calcite, dolomite and silica content were determined on the basis of hand sample observations and preliminary thin-section analysis. 


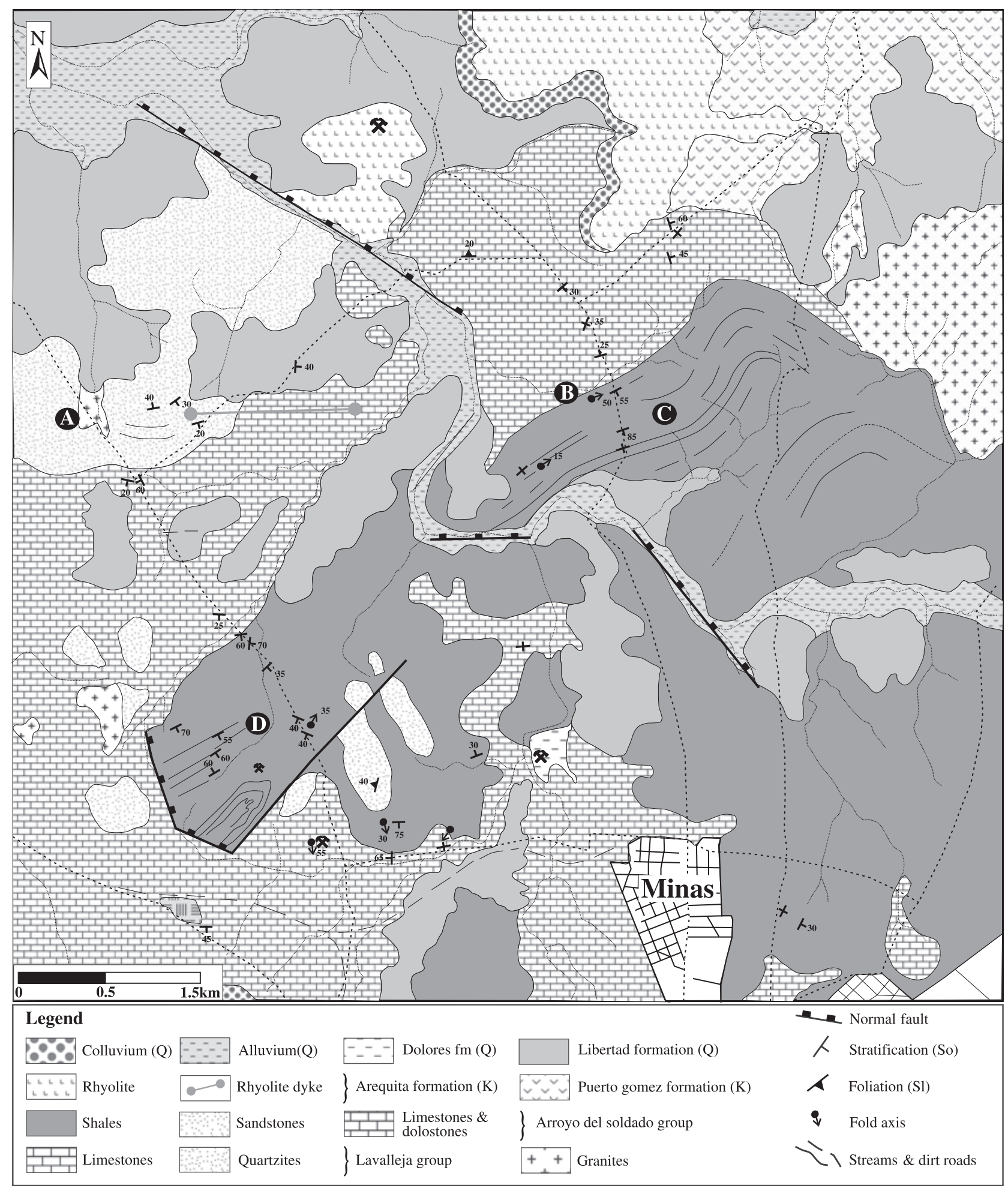

Fig. 10. Geological map of NE Minas town surrounding area (point F, Fig. 1B). Only facies belonging to the Yerbal Formation are present in the mapped area. Points A to D indicate location of sections shown in Fig. 12.

(Fig. 11E). The succession passes up-section into clean cherts, with variable iron and organicmatter content. In the middle part of this facies a $5 \mathrm{~m}$ thick fragmented chert bed is present. At the outcrop scale a strong stretching lineation parallel to the $S_{o}$ is observed; this lineation suggests a strike-slip displacement along the steep hills formed by cherts. Preliminary analysis

(c) 2007 The Authors. Journal compilation (c) 2007 International Association of Sedimentologists, Sedimentology, 55, 689-719 

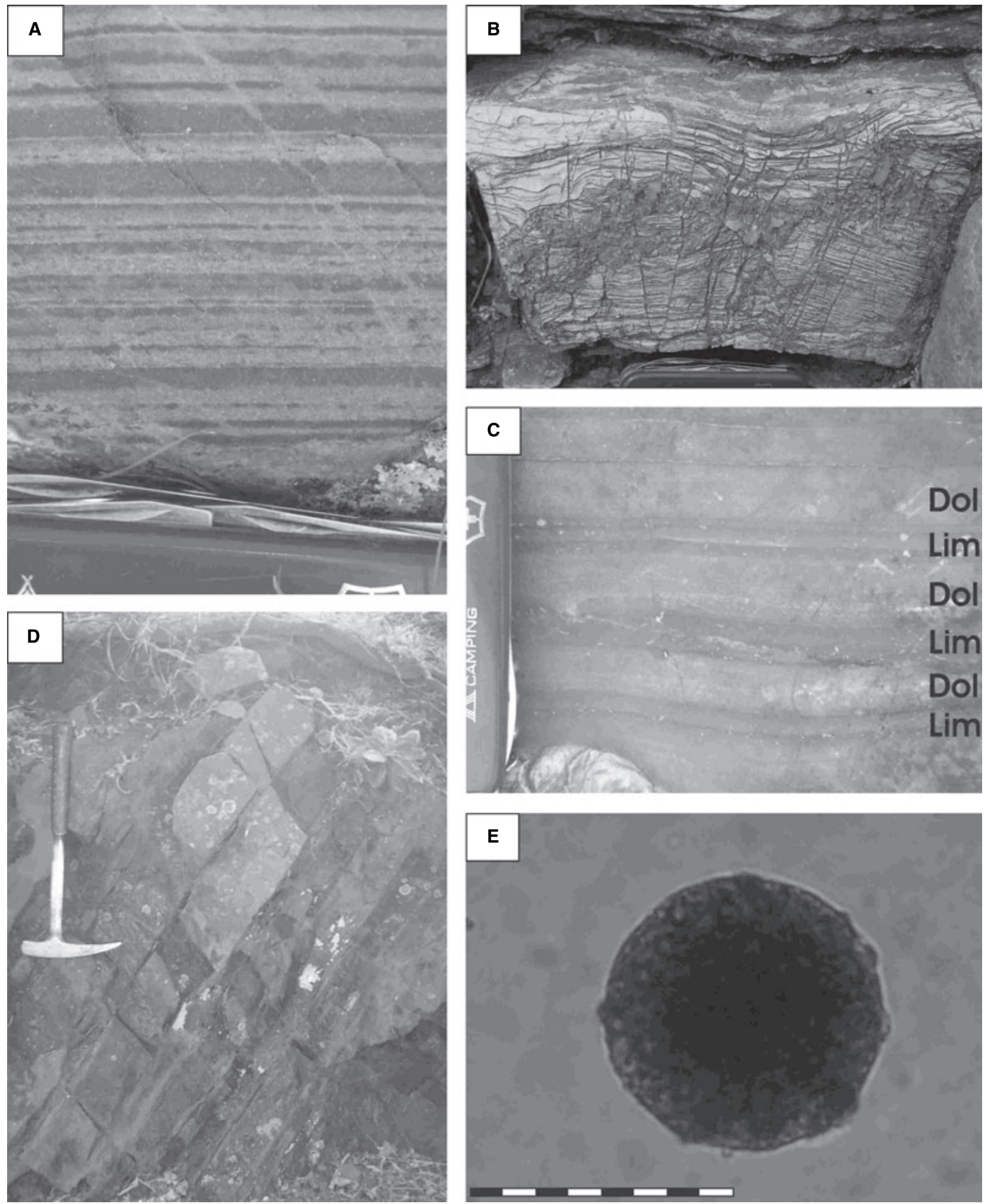

Fig. 11. (A) Finely laminated siltstones characteristic of the Yerbal Formation (Fig. 9). (B) Stromatolites in the lower Yerbal Formation (Fig. 12A). (C) Limestones-dolostones rhythmites. The layers are millimetres to decimetres thick (Polanco Formation; Fig. 9). (D) Iron formation from the upper Yerbal Formation (Fig. 12D). (E) Bavlinella faveolata Schepeleva (Vidal) occurring in palynological macerations of iron rich shales, Cerro Espuelitas Formation (Fig. 13). Scale: knife: $9 \mathrm{~cm}$; hammer: $40 \mathrm{~cm}$; bar: $10 \mu \mathrm{m}$. 


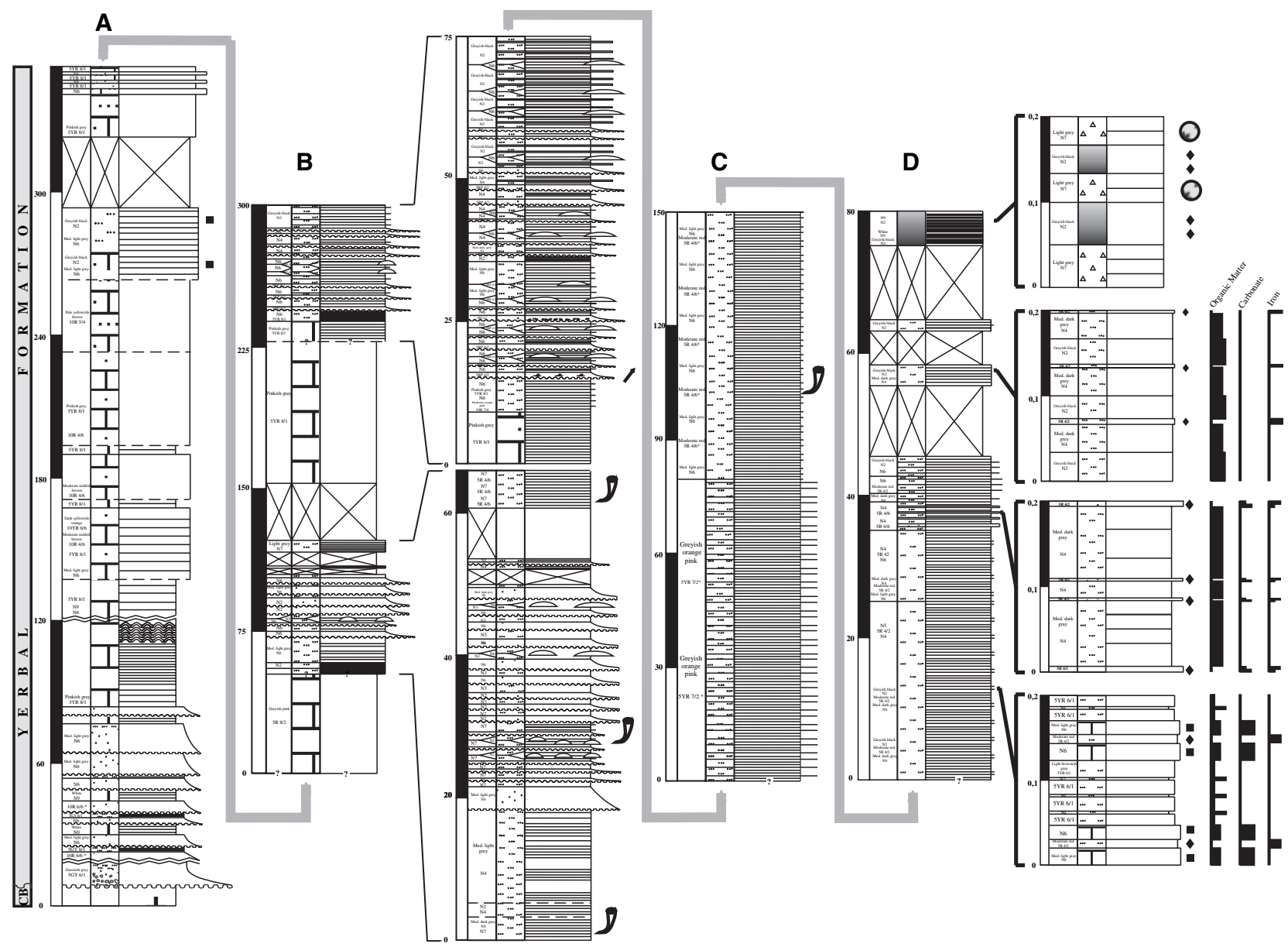

Fig. 12. Different sections of the Yerbal Formation in the area of NE Minas (see Fig. 10 for location). Symbols are the same as in Fig. 9.

of the structures present in the area enables confirmation of the presence of either a progressive strain regime (NE-SW), with rotation of structures, or two discrete deformation regimes with compression phases oriented NE-SW and ENE-WSW. Moreover, fragile deformation produced occasional iron-rich veins and silicacemented breccias, which had been interpreted as BIF and sedimentary breccias. Therefore, the Cerro Espuelitas Formation is redefined as dominated by shales and cherts. Even though ironrich rocks are present, BIF and associated breccias were not documented.

\section{Arroyo de la Pedrera Group}

Montaña \& Sprechmann (1993) proposed the Arroyo de la Pedrera Formation, which consists of the Cerros San Francisco Member and Cerro Victoria Member. The Cerros San Francisco Member includes sandstones and siltstones, showing well-preserved sedimentary structures, and represents a fining-upward and thinningupward cycle. According to these authors, the overlying Cerro Victoria Member is characterized by stromatolites and micritic limestones at the base, oolitic calcarenites and micritic limestones in the middle part of the succession and stromatolitic limestones interbedded with micritic limestones and organic-rich chert layers at the top. Even though dolomite has not been recognized previously, almost the whole unit is composed of dolostones ('post-depositional' dolomites). The type area is located to the NW of Illescas, in the Florida Department, where a continuous $\sim 600 \mathrm{~m}$ thick succession is exposed (Montaña \& Sprechmann, 1993) (location H; Fig. 1B). Gaucher et al. (1996) promoted both members to formational rank and, due to an apparent stratigraphic continuity, included them in the Arroyo del Soldado Group. Based on previously reported $\delta^{13} \mathrm{C}$ values and the stromatolite community, ichnofossil assemblage and ichnofabrics, Sprechmann et al. (2004 and references therein) placed the Cerro 


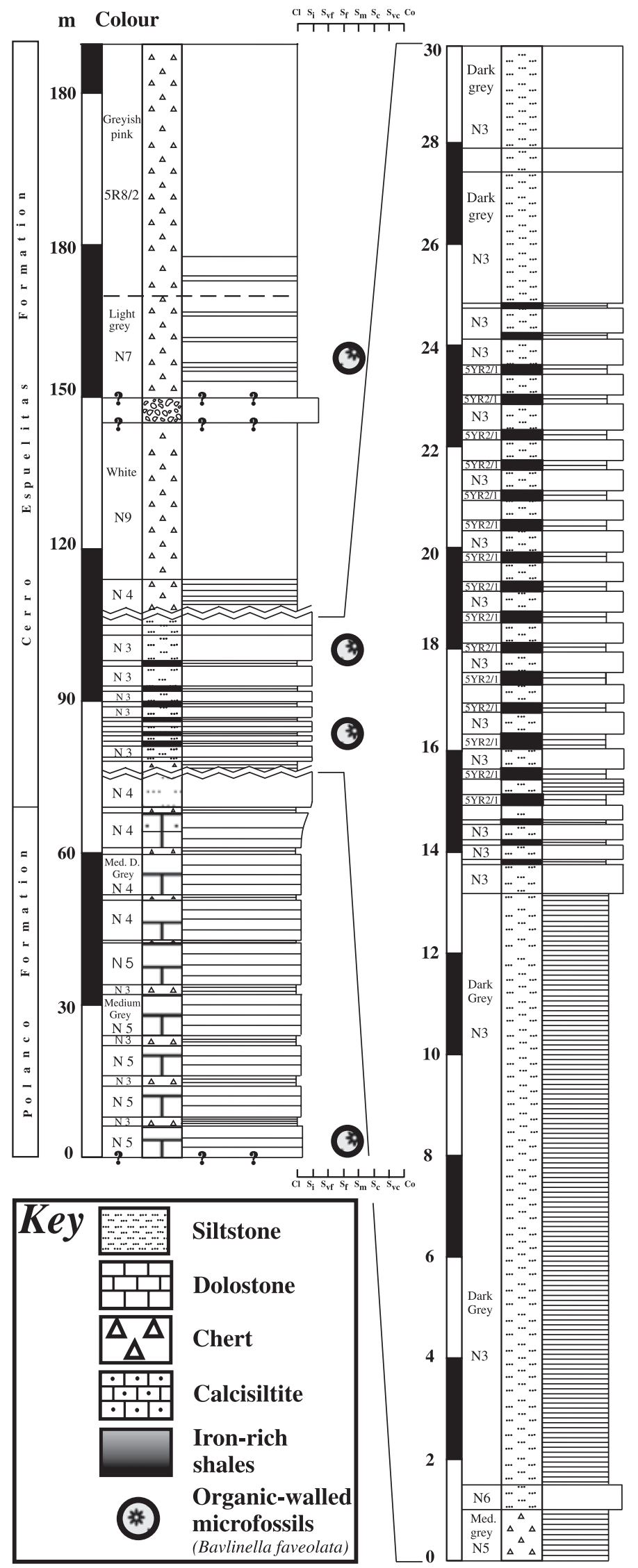

Fig. 13. Stratigraphic column of the Cerro Espuelitas Formation, showing the stratotype of the unit (point G, Fig. 1B). 
Victoria Formation in the lowermost Cambrian (542 to $535 \mathrm{Ma}$ ). These authors described a low-diversity stromatolite community and a low-diversity trace fossil association (Thalassinoides-Gyrolithes-Palaeophycus assemblage), both of which would confirm a Cambrian age. Sprechmann et al. (2004) concluded that the presence of trace fossils would constitute the best criterion for locating the unit in the lower Cambrian. However, the illustrated structures resemble diagenetic concretions of inorganic origin, and micropalaeontological studies carried out in the underlying Piedras de Afilar Formation reveal microbiota similar to that of the Arroyo del Soldado Group of Ediacaran age (see below). Although information is not yet conclusive, ongoing micropalaeontological research should determine either that the Arroyo de la Pedrera Group is of Cambrian age or that the typical organic-walled microfossils occurring in the Arroyo del Soldado Group (Ediacaran) extend into the Cambrian.

Aubet (2005) presented a detailed sedimentological and stratigraphical study of the Piedras de Afilar Formation, which is correlated with the Cerros San Francisco Formation (see also Aubet et al., 2005). Following recommendations of the International Stratigraphic Guide (Murphy \& Salvador, 1999), the Cerros San Francisco name is replaced by the earlier defined Piedras de Afilar Formation (Jones, 1956). The relationship between the Cerro Espuelitas Formation and the Cerros San Francisco Formation (Fig. 2), originally interpreted as conformable by Gaucher et al. (1996), has not been corroborated in this study. Instead, the later unit rests directly on an angular unconformity to the pre-Ediacaran basement. Therefore, following the original name proposed by Montaña \& Sprechmann (1993), the Arroyo de la Pedrera Formation (hosting the Piedras de Afilar and the Cerro Victoria units) is elevated to group status and separated from the Arroyo del Soldado Group (Fig. 2). Considering new information, a brief description of the Piedras de Afilar Formation is given below. For a recent description of the Cerro Victoria Formation see Sprechmann et al. (2004).

\section{Piedras de Afilar Formation}

The Piedras de Afilar Formation was formally defined by Jones (1956) as a siliciclastic fining and thinning-upward succession, composed of sandstones, shales and limestones; these rest on the Palaeoproterozoic basement in the southeastern area of the Piedra Alta Terrane (see
Fig. 1A and B; location I). Coronel et al. (1982) presented the first detailed geological map of the area. The most recent and comprehensive study by Aubet (2005) described the stratigraphy and facies associations of the unit (Fig. 14). At the Piedras de Afilar hills, where the basal contact with the underlying Palaeoproterozoic basement and its neostratotype are exposed, the section is up to $600 \mathrm{~m}$ thick and consists of two distinct units that are treated herein as lower and upper intervals. The lower part is $\sim 400 \mathrm{~m}$ thick and constitutes a sandstone-dominated interval, with subordinate siltstones and thin conglomerates interbedded at the base. Individual sandstone bodies have coarse-grained bases, commonly displaying planar cross-beds; these grade upwards into medium-grained quartz arenites with trough cross-stratification and ripple cross-lamination indicating waning flow deposits. Interbedded reddish fine-grained sandstone grading to siltstones have been described. Compositionally, the sandstones are sub-arkosic with zircon, sphene and tourmaline present as accessory minerals. The upper 150 to $200 \mathrm{~m}$ consists of purple siltstones and minor shales dominated by planar lamination, occasionally interbedded with thin sandstones layers. At the top of this unit, a gradational sedimentary contact with the overlying carbonate unit is observed (Fig. 14). The authors regard limestone strata above the siliciclastic succession as equivalent to the Cerro Victoria Formation.

On the basis of lithostratigraphy, the Piedras de Afilar Formation was correlated tentatively with the Cerros San Francisco Formation of the Arroyo del Soldado Group (Aubet et al., 2005). New field research permits correlation on the basis of the following characteristics: (i) both rest directly on pre-Ediacaran basement and are overlain by a carbonate unit; (ii) both represent a fining upwards succession; (iii) siltstones are always dominant in the upper interval; (iv) they present similar bimodal palaeocurrent patterns: $\sim \mathrm{N}-\mathrm{S}$ and $\sim \mathrm{E}-\mathrm{W}$; $(\mathrm{v})$ their facies assemblages and sandstones petrofacies are almost identical; (vi) they have Palaeoproterozoic Nd model ages ( $1.9 \mathrm{Ga})$; and (vii) both units are intruded by the Sierra de las Animas Complex (Cambrian) and other Cambrian granites. Moreover, micropalaeontological studies in the Piedras de Afilar Formation have shown that they contain similar organic-walled microfossils, including the most abundant and widely distributed species of the Arroyo del Soldado Group (Soldadophycus bossii). The microbiota recovered from the 


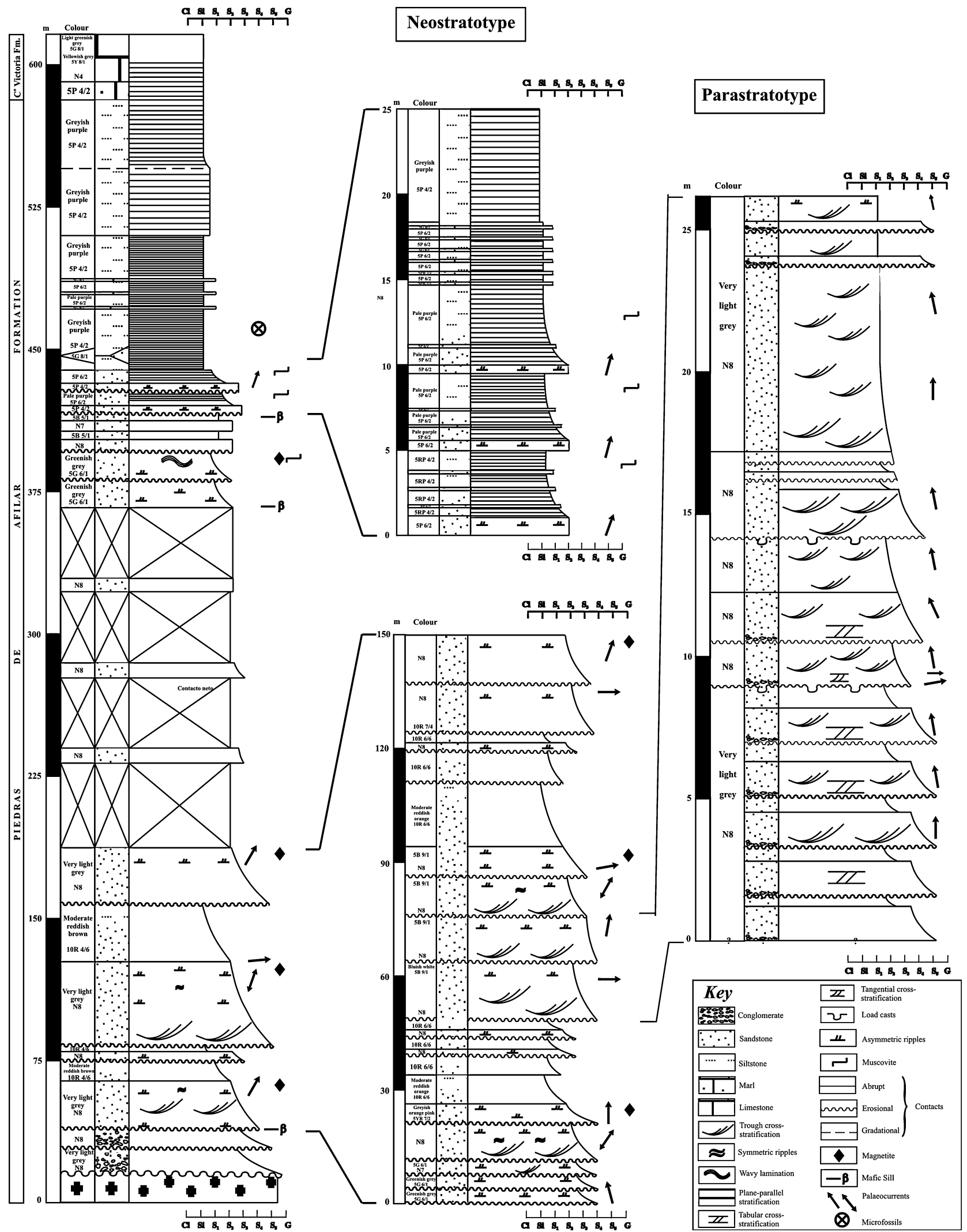

Fig. 14. Neostratotype and parastratotype of the Piedras de Afilar Formation (point I, Fig. 1B). 
Piedras de Afilar Formation is characterized by low diversity, with Bavlinella faveolata, Myxococcoides minor, Spumosina rubiginosa and Soldadophycus bossii being the most dominant (Fig. 15).
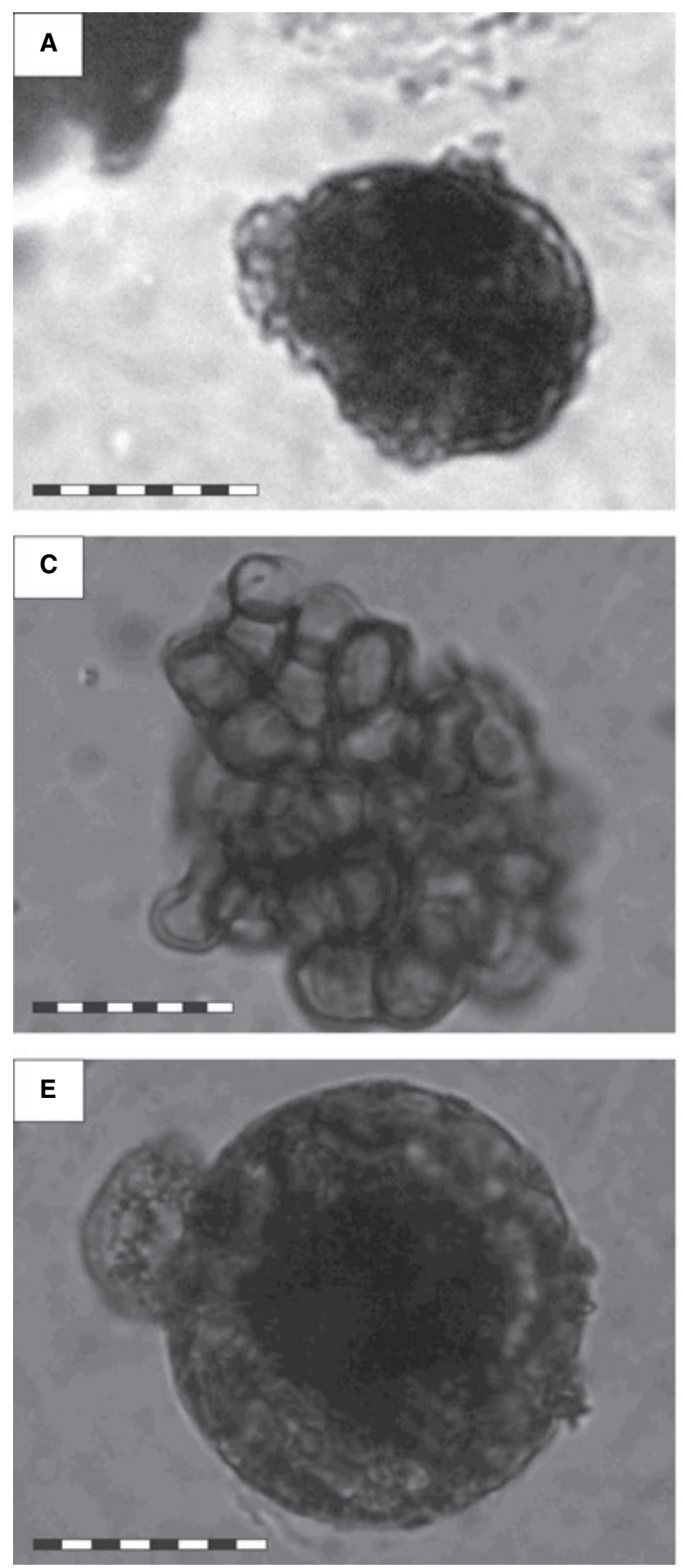

\section{DISCUSSION}

The evidence from Ediacaran to lowermost Cambrian units of Uruguay as a whole, outlined above, suggests significant environmental
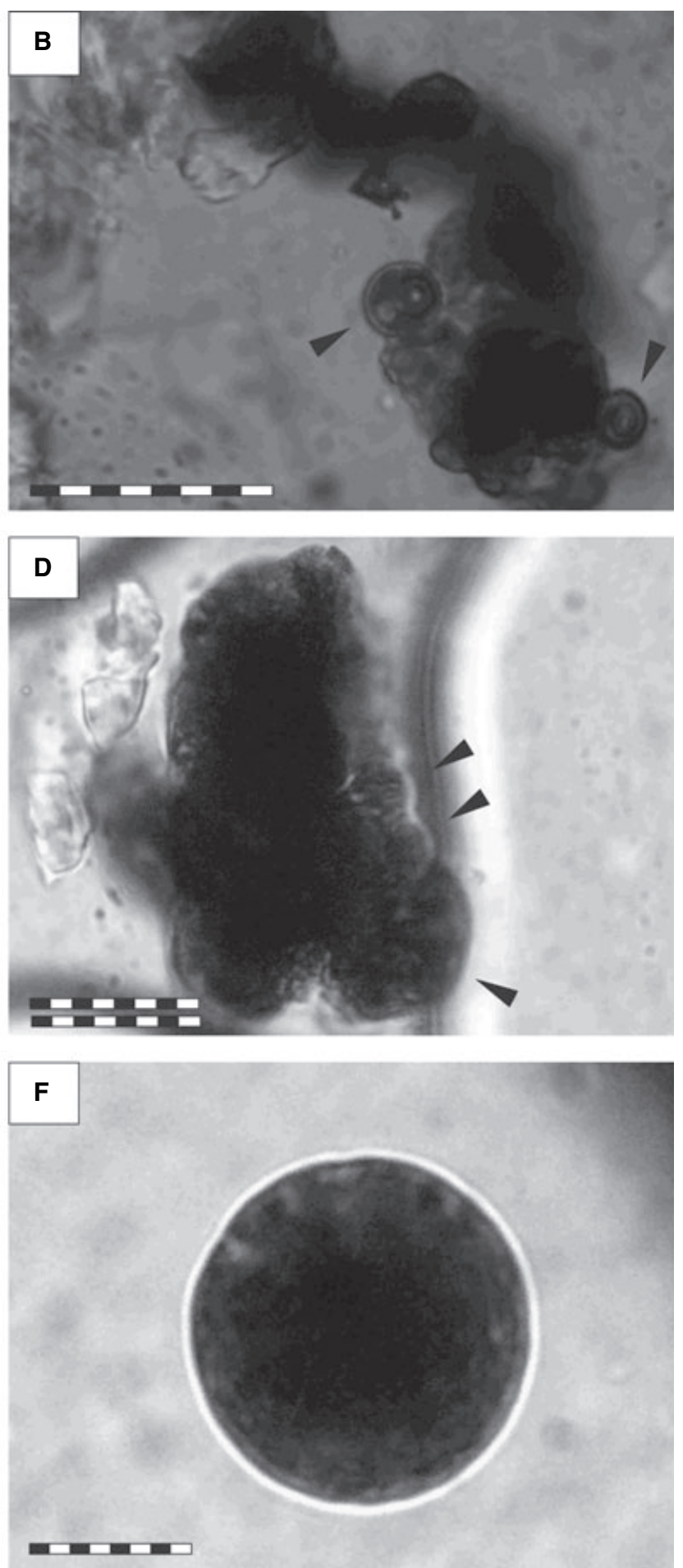

Fig. 15. Organic-walled microfossils from siltstones of the Piedras de Afilar Formation (Fig. 14). (A, B) Bavlinella faveolata Schepeleva (Vidal, 1976). (C, D) Soladophycus bosii Gaucher et al. (1996). (E, F) Spumosina rubiginosa Andreeva, emend. Jankauskas and Medvedeva, in Hoffman \& Jackson (1996). Simple scale bars represent $10 \mu \mathrm{m}$ and double $100 \mu \mathrm{m}$.

(C) 2007 The Authors. Journal compilation (c) 2007 International Association of Sedimentologists, Sedimentology, 55, 689-719 
changes during the deposition of the entire succession, consistent with previously reported data which suggest outstanding events in tectonics, biology, climatology and chemistry of the oceans and atmosphere (Knoll et al., 2006). In the following discussion, stratigraphic, sedimentological, palaeontological and geochronological evidence is examined with the aim of providing a useful insight into existing conditions during sedimentation.

\section{Basin synthesis}

Age

The available age data constraining each unit described in this study are variable. However, it is reasonable to propose that all the reported strata were deposited during the upper Ediacaran to lowermost Cambrian ( $\mathrm{ca} 585$ to $535 \mathrm{Ma}$ ). The relationship between the volcanism present in the Playa Hermosa Formation (Maldonado Group), reported by previous studies, and bimodal magmatism affecting the Las Ventanas Formation in its lower part, is not yet firmly established. Nonetheless the lateral and vertical continuity between sedimentary facies of both units is clear, suggesting a depositional age of $c a 590$ to $570 \mathrm{Ma}$. This observation is supported by the following: (i) the trachytes and syenites of the Sierra de Las Ánimas Complex (520 \pm 5 Ma; Bossi et al., 1993) and the Pan de Azúcar Granite $(559 \pm 28 \mathrm{Ma}$; Preciozzi et al., 1993) intrude the Las Ventanas Formation; (ii) the Puntas del Pan de Azúcar Lineament affecting the Las Ventanas Formation has a K/Ar age of $572 \pm 7$ Ma (Bossi \& Campal, 1992); (iii) preliminary micropalaeontological study supports an Ediacaran age for this unit (see below); and (iv) Sánchez \& Linares (1996) reported radiometric ages of basic rocks occurring at the base of the Las Ventanas Formation between $615 \pm 30$ and $565 \pm 30 \mathrm{Ma}(\mathrm{K} / \mathrm{Ar})$.

The age of the San Carlos Formation is less constrained, and the timing of emplacement of the interbedded rhyolites is unknown. Considering the field relationship between these lithologies and related granites, which yield ages between 570 and $590 \mathrm{Ma}$, it is reasonable to consider a similar age for this volcanism. The whole unit is deformed by the Sierra Ballena Shear Zone, wherein the last displacement is believed to have occurred at around $525 \mathrm{Ma}$ (Bossi et al., 1993).

Based on ${ }^{87} \mathrm{Sr} /{ }^{86} \mathrm{Sr}$ ratios Gaucher et al. (2004) proposed an age of $580 \mathrm{Ma}$ for the base of the Polanco Limestones Formation (Arroyo del
Soldado Group). However, it is well-known that the mineralized metazoan Cloudina occurs characteristically between $c a 550$ and $540 \mathrm{Ma}$ (Grotzinger et al., 1995; Saylor et al., 1998; Martin et al., 2000; Knoll et al., 2004; Hua et al., 2005). Given the fact that only the upper Yerbal Formation contains that fossil, the maximum age for the overlying Polanco Limestones Formation is $\mathrm{ca}$ 550 Ma. These data are in accordance with reinterpreted C-isotopic determinations (see below). Likewise, the assemblage of palynomorphs of the lower-middle Arroyo del Soldado Group supports the later date. On the other hand, absolute minimum age data are provided by intruding granites of 535 to 525 Ma.

Amthor et al. (2003) reported the extinction of Cloudina in Oman coincident with a negative excursion in the carbon isotope composition of the sea water in the Precambrian-Cambrian boundary. Conclusive information is needed to discard the possible presence of this boundary in the Polanco Formation. Nevertheless, the microbiota occurring in the Yerbal, Polanco, Barriga Negra and Cerro Espuelitas Formations can be assigned to the terminal Ediacaran (Vidal \& Moczydlowska-Vidal, 1997; Gaucher et al., 2003).

Based mainly on trace fossils and C-isotopic data a lowermost Cambrian age has been proposed for the Cerro Victoria Formation (Arroyo de la Pedrera Group) (Sprechmann et al., 2004). The occurrence of such large ichnofossils in carbonate sediments during the lowermost Cambrian is unusual (Crimes, 1992). Hence, the evidence is not conclusive and more research is needed to determine whether or not these structures are in fact organic. The Cerro Victoria Formation has been considered largely as composed of limestones (Montaña \& Sprechmann, 1993; Sprechmann et al., 2004); however, 'post-depositional' dolostones are the dominant lithologies and limestones are scarce. $\delta^{13} \mathrm{C}$ values of limestones therefore are not considered here. Cambrian volcanism and granitogenesis ( ca $530 \mathrm{Ma}$ ) provide an upper constraint on the age of deposition of the Arroyo de la Pedrera Group. Consequently, if the maximum age of deposition is constrained by the upper Ediacaran Arroyo del Soldado Group, the Precambrian-Cambrian boundary could be present within Arroyo del la Pedrera, but this is not yet established. Considering that an unconformity separates both groups, the Precambrian-Cambrian boundary can otherwise be located at the base of the Arroyo de la Pedrera Group, which represents a marine transgression and could be correlated with the worldwide 
transgression in the lowermost Cambrian (Vail et al., 1977).

\section{Basin evolution}

In Uruguay, an important extensional and synkinematic magmatic event took place during the Neoproterozoic, as represented by the Sierra de Ríos and Cerros de Aguirre Formations. The Sierra de Ríos Formation, located in the northern part of the Sierra Ballena Shear Zone, consists of ignimbrites, and rhyolitic flows and dykes, which are dated at $575 \pm 14 \mathrm{Ma}$ (Bossi et al., 1993). Associated with the Laguna de Rocha Shear Zone (Cuchilla Dionisio Terrane; see Fig. 1B) and deposited on a pull-apart basin type, the Cerros de Aguirre Formation is composed of pyroclastic and rhyolitic rocks yielding an age of $571 \pm 8 \mathrm{Ma}$ (Hartmann et al., 2002). Moreover, the Maldonado Group contains a syn-sedimentary bimodal volcanism, which presents similar ages (Pecoits, 2003b; Pecoits et al., 2004a, 2005b). Likewise, extensional basic magmatism represented by a mafic dyke swarm was emplaced at $c a 620 \mathrm{Ma}$ (Rivalenti et al., 1995), indicating an extensional regime in the Nico Pérez Terrane as well (Fig. 1B).

In close association with the regional magmatism, tectonic activity constituted a primary controlling element on the subsequent basin development. The Sierra Ballena Shear Zone is a high-strain transcurrent structure (Fig. 1A), operative between $c a 600$ and $580 \mathrm{Ma}$, which contributed significantly to the basin-fill architecture of the Uruguayan units described above. The Sarandí del Yí Shear Zone played a secondary role in this regard (see Fig. 1B). Other related features allow the authors to constrain the tecto-sedimentary analysis. For example, the Solís de Mataojo pluton is associated with the southern extreme of the shear sone. Structural studies carried out by Oyhantçabal et al. (2001) indicate that this synkinematic granitic body was intruded during the sinistral reactivation of the mega-fault due to the activity of the Sierra Ballena Shear Zone. The age of crystallization of the rock obtained is $584 \pm 13 \mathrm{Ma}(\mathrm{U} / \mathrm{Pb}$; Oyhantçabal, 2005). Also, synkinematic granitic bodies related to the activity of the Sierra Ballena Shear Zone yield ages between 570 and $590 \mathrm{Ma}$. Collectively, these features suggest an important tectono-magmatic activity during deposition of the Nico Pérez Terrane and the Cuchilla Dionisio Terrane.

In contrast, Gaucher et al. (2004), contend that the Arroyo del Soldado Group was deposited on a stable, Atlantic-type continental shelf during the Ediacaran-lowermost Cambrian; however, the available data do not support this model. All the aforementioned arguments, and the establishment of lithological, palaeontological and age similarities between the San Carlos Formation (Cuchilla Dionisio Terrane) and the Maldonado Group, located in the Nico Perez Terrane, favour the argument that both were joined by the Ediacaran period. Furthermore, the recent discovery of volcaniclastic rocks in the basal Yerbal Formation, and the apparent continuity between the Maldonado and Arroyo del Soldado Groups, make it unlikely that both sequences formed far apart and joined in a short span of time (ca $10 \mathrm{Ma}$ ) (Pecoits et al., 2005a,b). Rather, the present study suggests an extensional basin (strike-slip and late-orogenic extensional collapse basins) for the Maldonado Group and the San Carlos Formation. Following continental collision, the basin evolved into a foreland basin (Arroyo del Soldado and Arroyo de la Pedrera Groups) (see also Pecoits \& Oyhantçabal, 2004).

\section{Palaeoclimatology}

Recent radiometric ages have constrained better the timing of the Neoproterozoic glaciations (Allen et al., 2002; Bowring et al., 2003; Hoffmann et al., 2004). Independent evidence supports at least three glacial epochs: Sturtian, Marinoan (or older Varanger) and Gaskiers (Moelv or younger Varanger) (Hoffman \& Schrag, 2002; Knoll et al., 2004, 2006; Xiao et al., 2004; Condon et al., 2005; Halverson et al., 2005). Unlike the Marinoan and Sturtian glacial deposits, the Gaskiers episode lacks a well-developed cap carbonate unit, possibly suggesting that this glaciation was diachronous and not a global event. However, the presence of glacially related deposits and $\delta^{13} \mathrm{C}$ anomalies above the Marinoanaged diamictite is consistent with the occurrence of a third Neoproterozoic glaciation (Wonoka anomaly; see Halverson et al., 2005). Correlative deposits of the Gaskiers glaciation have been reported from Australia, Canada, USA, Norway, Scotland, China and western Africa (Xiao et al., 2004; Halverson et al., 2005). Even though this event was dated between $595 \pm 2$ and $570 \mathrm{Ma}$ (Thompson \& Bowring, 2000) and $<601 \pm 4$ Ma (Dempster et al., 2002), the age obtained by Bowring et al. (2003) for the Gaskiers in Newfoundland, ca 580 Ma, constitutes the best available datum. 
As stated above, the glacial deposits are characterized by diamictites, and extremely negative $\delta^{13} \mathrm{C}$ values can be observed in the related carbonates (Burns \& Matter, 1993; Calver, 2000; Jiang et al., 2002; Wang et al., 2002; Corsetti \& Kaufman, 2003). Furthermore, the glaciations predate the appearance of macroscopic Ediacaran animals (Narbonne, 2005), the fossil metazoan embryos and algae of the Doushantuo Formation (Xiao et al., 1998), and post-date the Doushantuotype acritarch assemblage (Zhou et al., 2002). Condon et al. (2005) recognized two $\delta^{13} \mathrm{C}$ negative excursions between 580 and $551 \mathrm{Ma}$. The former is linked to the glacial event, whereas the latter is not related to any known glaciation and constitutes one of the larger carbon isotopic excursions recognized (see also Saylor et al., 1998). Halverson et al. (2005) correlated this anomaly with the Gaskier-related event. Likewise, a recent study carried out by Le Guerroué et al. (2006), in the well-preserved Huqf Supergroup in Oman, shows the longest-lived and highest amplitude carbon isotopic record documented at around $600 \mathrm{Ma}$. Even though no glacial deposits occur in the succession, it is likely that this anomaly is correlated with the Gaskiers event. Moreover, no imprint of the anomaly registered by Condon et al. (2005) and Saylor et al. (1998) ca $551 \mathrm{Ma}$ is recognizable.

Diverse models have been proposed to explain the carbon isotopic composition and origin of cap dolostones and post-glacial limestones. In the case of the cap dolostones four (deglaciation-related) models have been proposed: (i) overturn of an anoxic deep ocean; (ii) catastrophically accelerated rates of chemical weathering because of super-greenhouse conditions following global glaciation (Snowball Earth Hypothesis); (iii) massive release of carbonate alkalinity from destabilized methane clathrates; and (iv) physical separation of the surface and deep ocean reservoirs, with cap dolostones formed primarily by microbially mediated precipitation of carbonate during algal blooms within a low salinity 'plumeworld' (see Shields, 2005 for review).

In Uruguay the first evidence of glacial influence on Neoproterozoic sequences was documented by Pazos et al. (1998) in the Playa Hermosa Formation. Pecoits (2002) proposed an arid climate for the Las Ventanas Formation and mentioned the existence of possible glacially related sedimentary features. Later Pecoits et al. (2005a) strengthened that hypothesis in reporting outsized clasts, in finely laminated siltstones, interpreted as dropstones. Previous proposals considered a Marinoan-aged glacial deposition for the lower and upper parts of the group (Pazos et al., 2003; Pecoits et al., 2005a). At present, taking into account the geochronological constraints, new field research and reinterpretation of previously presented information, the authors propose that the Maldonado Group records the Gaskiers Glaciation (Halverson et al., 2005); this observation also explains the apparent lack of 'cap carbonates' immediately overlying these deposits (see Fig. 16). The palaeomagnetic data available for Neoproterozoic rocks of Uruguay are still preliminary (Sánchez \& Rapalini, 2002). This research was carried out on igneous and sedimentary rocks of the Sierra de las Ánimas Complex and Playa Hermosa Formation, respectively. The study from the Playa Hermosa Formation, in particular, suggests that it may constitute another case of low latitude glaciation $\left(12 \cdot 7^{\circ}+9 \cdot 5^{\circ} /-8 \cdot 1^{\circ}\right)$. No geochemical analyses of the Maldonado Group have been performed.

In the lower Arroyo del Soldado Group, only four C-isotopic measurements of pink dolostones from the upper Yerbal Formation have been obtained (Gaucher et al., 2003). The dolomite yielded $\delta^{13} \mathrm{C}$ values between $+1 \cdot 17$ and $+2 \cdot 15 \%$ PeeDeeBelemnite (PDB), increasing up-section. Likewise, Boggiani (1998) and Gaucher et al. (2004) reported carbon isotope studies from the Polanco Limestones Formation. The strongest negative peak reported $(-3 \cdot 3 \%$ PDB) occurred in the middle of the unit with an underlying positive peak $(+5 \cdot 3 \%$ PDB). Considering the stratigraphic location of Cloudina and its range (see above), these peaks can be correlated with the slightly negative $(-1.5 \% \mathrm{PDB})$ and positive (+6\% PDB) excursions reported by Saylor et al. (1998) for the Kuibis Subgroup (Namibia) at $\sim 548$ and $\sim 549 \mathrm{Ma}$, respectively. According to the same authors, similar trends present in Oman would indicate ages of $\sim 550$ and $\sim 551.5$ respectively. Recently, Condon et al. (2005), integrating isotope and radiometric data from Oman, China, Namibia and Russia, suggested a global negative $\delta^{13} \mathrm{C}$ anomaly at $\mathrm{Ca} 551 \mathrm{Ma}$ unrelated to obvious glacial episodes (Fig. 16). No glacial features have been observed in the Arroyo del Soldado Group.

\section{Palaeobiology}

Throughout much of the history of the Earth, biology has played a fundamental role in driving low-temperature geochemical reactions (for a 


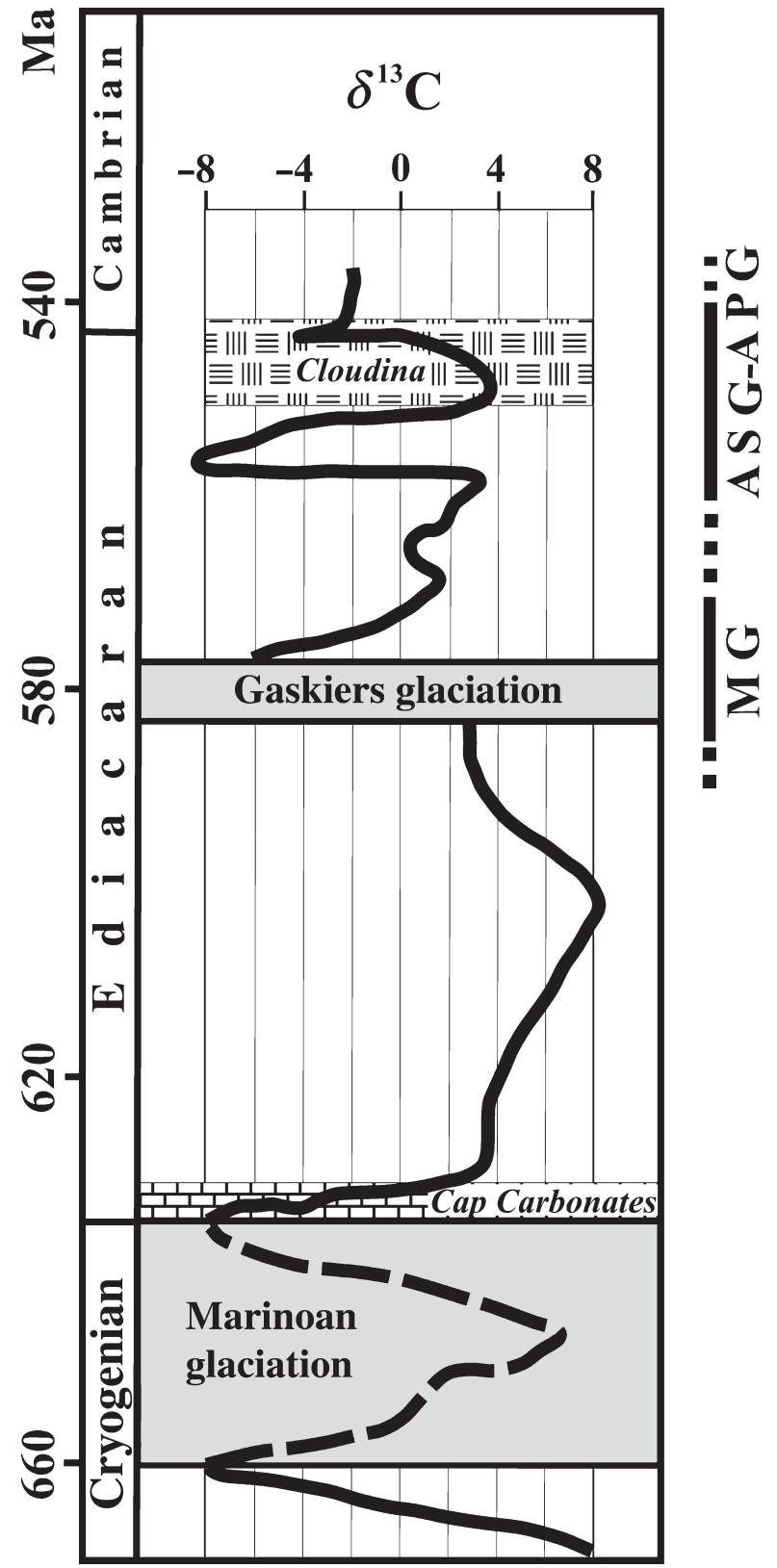

Fig. 16. Schematic diagram comparing biochron of index fossil Cloudina, cap carbonates location, globally correlated $\delta^{13} \mathrm{C}$ excursions spanning the inferred Marinoan and Gaskiers glaciations, and proposed age of deposition of the Maldonado (MG), Arroyo del Soldado (ASG) and Arroyo de la Pedrera (APG) Groups. See text for discussion. (data from Knoll et al., 2004, 2006; Condon et al., 2005; Halverson et al., 2005).

recent review see Konhauser, 2006); this is certainly the case during the Neoproterozoic, when significant changes in ocean and atmospheric chemistry were taking place. For example, as the oceans became more oxygenated, through increased cyanobacterial activity, there was an attendant deepening of the oxic-anoxic interface in the oceans. At this stage, $\delta^{34} \mathrm{~S}$ values between pyrite and sulphates approached $70 \%$, indicating that wide-scale initiation of the oxidative sulphur cycle, possibly driven by a combination of newly evolved non-photosynthetic sulphide-oxidizing and sulphur-disproportionating bacteria, had taken place (Canfield \& Teske, 1996). Increased levels of $\mathrm{O}_{2}$ could even have facilitated the emergence of metazoans, primitive soft-bodied, multicellular animals, on the shallow sea floor, as early as ca 600 Ma (Valentine, 2004; Narbonne, 2005). Clearly, the Neoproterozoic represents a time of significant biological innovation and, not surprisingly, it has been proposed that a causal link exists between environmental change and the diversification of life (Vidal \& Knoll, 1982; Schopf, 1991; Fedonkin, 1992; Knoll, 1994; Seilacher, 1996; Conway-Morris, 2000; Walter et al., 2000; Moczydlowska, 2005). Specifically, the Ediacaran records a proliferation of phytoplankton (acritarchs), metazoa and vendobionta that show an increase in morphological complexity.

The Ediacaran biota was eventually eclipsed near the Precambrian-Cambrian boundary (545 Ma) by more complex animal phyla, many of them skeletal with modern body plans and displaying a higher degree of behavioural sophistication, in what is known as the 'Cambrian radiation' (Knoll \& Carroll, 1999). The cause for the decline in Ediacaran fauna remains speculative, but it probably involved a combination of factors, such as a rise in predation, increased competition for nutrients, more active bioturbation, or a mass extinction event prompted by an environmental perturbation. Its disappearance from the rock record may also simply be due to reduced preservation potential relative to organisms that evolved mineralizing capabilities. Indeed, Brennan et al. (2004) suggested that a surge in calcium concentrations during the early Cambrian spurred the onset of calcium carbonate biomineralization, which led to a number of marine biota developing calcium carbonate shells, in addition to the advent of calcifying cyanobacteria.

The Ediacaran and lower Phanerozoic successions of Uruguay offer the possibility to explore different ecological aspects of the ocean environment in which microbial and more complex organisms evolved. Accordingly, the occurrence of a well-exposed mixed siliciclastic-carbonate sequence with the development of other chemical sediments, such as cherts and iron formations, is indicative of significantly variable palaeooceano- 
graphic conditions. Furthermore, the geological evidence shows important climatic oscillations from glacially influenced sedimentation at the base towards an arid environment at the top of the sequence.

A remarkable aspect of the Uruguayan succession is a palaeontological record consisting of organic-walled and skeletal fossils that display a clear exploitation of different ecological niches. One such example is the occurrence of the distinctive shelly fauna, including Cloudina, which is restricted to particular facies of the uppermost Yerbal Formation and abruptly disappears at the boundary with the Polanco Limestones Formation. Thus, while some authors have attributed the advent of biomineralization to important increments of the sea water Ca concentration, the explanation seems to be more complex. Likewise, significant alterations in abundance and assemblages of organic-walled microfossils took place at this boundary. Indeed, preliminary palynological macerations have shown the occurrence of different well-preserved assemblages of organic-walled microfossils depending on the nature of the unit, which reinforces the previous observations of Gaucher (2000), who suggested alternations of two different assemblages. Another interesting observation is that the taxon Bavlinella faveolata, identified as an important component of the phytoplankton assemblage in iron-rich facies of the Cerro Espuelitas and Yerbal Formations, becomes very scarce in the carbonate rhythmites of the Polanco Formation. Perhaps this observation reflects specific palaeoecological conditions (i.e. nutrient availability, oxygen concentration, etc.) that were met during times of Fe deposition (see Gaucher, 2000).

Another important aspect is the understanding of the relationship between biologically mediated processes and unusual deposits such as BIF or primary dolostones. In fact, the possible role of micro-organisms has been considered in many genetic models of BIF. For instance, LaBerge et al. (1987) regarded microbiota as essential participants in the process, whereas Walter \& Hofmann (1983) gave a list of fossil organisms identified in BIF but assumed a conservative view about the role in precipitating iron. Recent experimental biological studies highlight the potential magnitude of microbial activity as a mechanism of ferric iron precipitation (Konhauser et al., 2002; Kappler et al., 2005). However, its importance in the deposition of IF remains conjectural.

\section{Rhythmites}

Rhythmically bedded carbonates occur in the basal Yerbal Formation; these are intercalated with grey cherts and constitute the predominant facies of the Polanco Limestones Formation (Goñi \& Hoffstetter, 1964; Preciozzi \& Fay, 1988; Preciozzi et al., 1988; Díaz et al., 1990; Gaucher, 2000). The beds consist of millimetre to decimetre-scale alternations of limestone and dolostone, typically displaying sharp contacts. The limestone beds show variable grain-size, parallel bedding and cross-stratification, including hummocky, which indicates a marine wave-dominated origin (Bossi \& Navarro, 1991; Gaucher, 2000). The dolostone layers are finer-grained, but millimetre-thick parallel laminations and normal grading are common. Authigenic albite has been reported by Gaucher (2000) from both limestone and dolostone, which might be indicative of hypersaline, alkaline and marine-evaporitic conditions. The dolostones also contain organic matter and pyrite, but it is unclear whether this suggests a primary feature (see below).

Present-day low-temperature dolomite occurrences are restricted to marine or hypersaline coastal environments such as coastal sabkhas of Abu Dhabi, tidal flats of Andros Island in the Bahamas, Coorong lakes of South Australia and the coastal lagoon, Lagoa Vermelha in Brazil (Vasconcelos \& McKenzie, 1997 and references therein). Low-temperature inorganic synthesis of dolomite is difficult to achieve under laboratory conditions without the presence of micro-organisms, in particular sulphate-reducing bacteria (SRB) (see Vasconcelos \& McKenzie, 1997; Warthmann et al., 2000; Vasconcelos et al., 2006). The role of SRB in dolomite formation is two-fold. Firstly, the process of sulphate reduction overcomes the kinetic barrier to dolomite formation by increasing the $\mathrm{pH}$ and alkalinity, and by removing sulphate, which is a known inhibitor to dolomite formation. Secondly, the cell surfaces of SRB concentrate $\mathrm{Ca}^{2+}$ and $\mathrm{Mg}^{2+}$ cations around the cell. Once bound, these cations subsequently serve as favourable adsorption sites for $\mathrm{CO}_{3}^{2-}$ ions (van Lith et al., 2003).

In preliminary petrographic observations of the Polanco Limestones Formation rhythmites, the authors have observed that pyrite is relatively scarce; this observation suggests that sulphate reduction is not the main control promoting the dolomite formation. At present, the data from the Polanco Limestones Formation are insufficient to address this question further; however, it seems 
clear that the 'Polanco event' was controlled by palaeooceanographic parameters.

\section{Iron formations}

Bracketing the rhythmites of the Polanco Limestones Formation are iron-rich rocks, interpreted as BIF. These rocks display centimetre alternation of chert and iron-rich layers, yet, they do not show the characteristic microbanding of ArcheanPalaeoproterozoic BIF. The significance of BIF in the Neoproterozoic is not completely understood. Along with major deposits at Urucum, Brazil, the Rapitan in north-west Canada, the Braemar and Holowilena Formations in Australia, and the Damara Belt in Namibia, South Africa, these BIF have been considered a special case when compared with the more extensive Palaeoproterozoic deposits. The deposition of BIF has often been linked to the termination of global glaciations, when ocean circulation was restored after the ice sheets melted (Kirschvink, 1992; Klein \& Beukes, 1993; Hoffman et al., 1998b). Taking into account the associated glaciogenic deposits and hydrothermal imprint, others have suggested an alternative theory involving glaciation of a Red Sea-type rift environment. This theory helps to explain evidence of rift activity in some BIF, such as significant facies and thickness changes, and association with volcanic rocks (see Young, 2002).

Virtually no BIF from the upper Vendian have been described. Gaucher et al. (2004) suggested that deposition of the BIF took place on a shelf, due to enhanced upwelling of nutrient-rich waters and consequent production of phytoplankton blooms during greenhouse conditions (see Button, 1982, for details about the model). However, as stated above, the depositional geological setting of the group does not correspond to an Atlantic-type continental shelf, in which the model was developed, and the age of the whole Arroyo del Soldado Group is younger than the Gaskiers glacial event which is problematic for that model (see Pecoits et al., 2004b for an alternative model). Thus, in the absence of more evidence, the mechanism that triggered the iron precipitation remains unresolved.

\section{CONCLUSIONS}

Field-based research with preliminary micro-palaeontological and petrographical data, and a re-assessment of previous research, was carried out on late Neoproterozoic (volcano) sedimentary units, in south-eastern Uruguay. The studied units comprise the Maldonado, Arroyo del Soldado and Arroyo de la Pedrera Groups, which together contain dropstones, diamictites, banded iron formations, pink dolostones, limestonedolostone rhythmites, thick stromatolitic/oolitic dolostones, organic-walled and skeletal fossils. The estimated time of deposition for these successions ranges from ca 590 to $535 \mathrm{Ma}$, thereby indicating an upper Ediacaran-lowermost Cambrian age. This work shows a temporal correlation between sedimentation and significant changes in global climate and palaeobiology. Also the formations represent the tectonic re-configuration of depositional basins corresponding to the final stages of the SW-Gondwana assembly.

Based on this work, it is suggested that the basal Maldonado Group, which contains ice-rafted diamictites and dropstones, records the Gaskiers Glaciation ( $\sim 580 \mathrm{Ma})$. The Arroyo del Soldado Group is more likely to represent post-glacial conditions and, possibly, changes in ocean chemistry; this is demonstrated by the presence of distinctive siliciclastic and chemical sediments, and variations in biota content. Based on the radiometric and biostratigraphic data a maximum age of $560 \mathrm{Ma}$ is proposed for the base of the whole group (Yerbal Formation). Considering the new information, preliminary carbon-isotopic determinations from the Polanco Limestones Formation compares well with the worldwide negative excursion recorded at ca $551 \mathrm{Ma}$, which is thought to be unrelated to glacial events. Although there is no conclusive evidence, the uppermost Arroyo de la Pedrera Group is probably lowermost Cambrian in age. Contrary to previous models, which invoke an Atlantic-type passive margin during the Ediacaran in Uruguay, it is suggested that transtensional basins developed, evolving towards a foreland basin in the later stages of the continental collision.

The study not only permits the establishment of a reasonable stratigraphic framework for Neoproterozoic rock successions in Uruguay, but it helps facilitate a better understanding for the origin and significance of peculiar deposits such as BIF, limestone-dolostone rhythmites, and thick stromatolitic/oolitic dolostones hosting a diverse fossil assemblage. More detailed studies, however, are necessary to interpret whether these features exist just on a regional scale, or whether they are correlative with worldwide events, such as 'Snowball Earth' glaciations, late-stage BIF deposition and the advent of animal skeletons. 


\section{ACKNOWLEDGEMENTS}

The constructive comments of two anonymous reviewers on the manuscript are appreciated. This article is a contribution to projects IGCP 512 (Neoproterozoic Ice Ages) and IGCP 493 (The rise and fall of the Vendian biota). Aspects of the research were funded in part by Natural Science and Engineering Council of Canada Discovery Grants to KOK. and MKG.

\section{REFERENCES}

Allen, P.A., Bowring, S.A., Leather, J., Brasier, M., Cozzi, A., Grotzinger, J.P., McCarron, G. and Amthor, J. (2002) Chronology of Neoproterozoic glaciations: new insights from Oman. In: Int. Sedimentological Congress 16th International Association of Sedimentologists, pp. 7-8, Johannesburg (Abstract Volume).

Amthor, J.E., Grotzinger, J.P., Schröder, S., Bowring, S.A., Ramezani, J., Martin, M.W. and Matter, A. (2003) Extinction of Cloudina and Namacalathus at the PrecambrianCambrian boundary in Oman. Geol. Soc. Am. Bull., 31, 431434.

Aubet, N. (2005) Sedimentología y consideraciones estratigráficas de la Formación Piedras de Afilar, Canelones. Unpublished Grad. Thesis. Facultad de Ciencias, Montevideo, 41 pp.

Aubet, N., Pecoits E., Sánchez, B.L. and Pazos, P. (2005) Consideraciones estratigráficas de la Formación Piedras de Afilar y su correlación con otras unidades neoproterozoicas del Uurugay. In: XII Congreso Latinoamericano de Geología. Resúmenes extendidos, Actas Cd, Quito.

Basei, M., Siga, O., Jr., Masquelin, H., Harara, O., Reis Neto, J. and Preciozzi, F. (2000) The Dom Feliciano Belt of Brazil and Uruguay and its foreland domain, the Río de la Plata Craton. In: Tectonic Evolution of South America (Eds U. Cordani, Milani, E., Thomaz F. A. and Campos, D), 1st edn, pp. 311-334.

Boggiani, P.C. (1998) Análise estratigráfica da Bacia Corumbá (Neoproterozoico) -Mato Grosso do Sul-. Unpublished PhD thesis, Universidade de São Paulo, São Paulo.

Bossi, J. (2003) Estratigrafía del Precámbrico de Uruguay: terrenos tectono-estratigráficos y geocronología. Revista de la Sociedad Uruguaya de Geología. In: Estratigrafía del Precámbrico del Uruguay (ed. E. Pecoits), Rev. Soc. Uruguay. Geol. Spec. Publ., 1, 1-17.

Bossi, J. and Campal, N. (1992) Magmatismo y tectónica transcurrente durante el Paleozoico Inferior en Uruguay. In: Paleozoico Inferior de Iberoamérica (Eds J.G. GutiérrezMarco, J. Saavedra and I. Rabano), 1st edn, pp. 343-356. Universidad de Extremadura, Mérida.

Bossi, J. and Navarro, R. (1991) Geología del Uruguay. Universidad de la República, Montevideo, 970 pp.

Bossi, J., Cingolani, C., Lambias, E., Varela, R. and Campal, N. (1993) Características del magmatismo post-orogénico finibrasiliano en el Uruguay: formaciones Sierra de Ríos y Sierra de Ánimas. Rev. Brasil. Geocienc., 23, 282-288.

Bossi, J., Ferrando, L., Montaña, J., Campal, N., Morales, H., Gancio, F., Schipilov, A., Piñeyro, D. and Sprechmann, P. (1998) Carta Geológica del Uruguay. Escala 1:500·000. Versión digital. Geoeditores, Montevideo.
Bowring, S., Myrow, P., Landing, E., Ramezani, J. and Grotzinger, J. (2003) Geochronological constraints on terminal Neoproterozoic events and the rise of metazoans. Geophys. Res. Abstr., 5, 219.

Brennan S.T., Lowenstein T.K. and Horita, J. (2004) Seawater chemistry and the advent of biocalcification. Geology, 32, 473-476.

Burns, S.J., and Matter, A. (1993) Carbon isotopic record of the latest Proterozoic from Oman. Eclogae Geol. Helv., 86, 595607.

Button, A. (1982) Sedimentary iron-deposits, evaporates, and phosphorites. State of the art report. In: Mineral Deposits and the Evolution of the Biosphere (Eds H.D. Holland and M. Schidlowski), 1st edn, pp. 259-273. Springer, Berlin.

Calver, C.R. (2000) Isotope stratigraphy of the Ediacarian (Neoproterozoic III) of the Adelaide Rift Complex, Australia, and the overprint of water column stratification. Precambrian Res., 100, 121-150.

Canfield, D.E. and Teske, A. (1996) Late Proterozoic rise in atmospheric oxygen concentration inferred from phylogenies and sulfur-isotope studies. Nature, 382, 127-132.

Condon, D., Zhu, M., Bowring, S. and Wang, W. (2005) U-Pb ages from the Neoproterozoic Doushantuo Formation, China. Science, 308, 95-98.

Conway-Morris, S. (2000) The Cambrian "explosion": slowfuse or megatonnage? Proc. Natl Acad. Sci. USA, 99, 44264429.

Coronel, N., Oyhantçabal, P. and Spoturno, J. (1982) Consideraciones estructurales de la Formación Piedras de Afilar en su área tipo, en los alrededores de la estación de Piedras de Afilar, Depto. de Canelones, Uruguay. In: V Congreso Latinoamericano de Geología, pp. 48-60. Actas, AGA, v.1., Buenos Aires.

Corsetti, F.A. and Kaufman, A.J. (2003) Stratigraphic investigations of carbon isotope anomalies and Neoproterozoic ice ages in Death Valley, California. Geol. Soc. Am. Bull., 115, 916-932.

Crimes, P.T. (1992) The record of trace fossils across the Proterozoic-Cambrian boundary. In: Origin and Early Evolution of the Metazoa (Eds J.H. Lipps and P.W. Signor), 1st edn, pp. 177-202. Plenum Press, New York.

Díaz, R., Albanell, H. and Bossi, J. (1990) Carta geológica del Uruguay, Hoja F-24 Cerro Partido, Escala 1:100·000. Memoria explicativa. DINAMIGE-UdelaR, Montevideo.

Dempster, T.J., Rogers, G., Tanner, P.W.G., Bluck, B.J., Muir, R.J., Redwood, S.D., Ireland, T.R. and Paterson, B.A. (2002) Timing of deposition, orogenesis and glaciation within the Dalradian rocks of Scotland: constraints from U-Pb zircon ages. J. Geol. Soc. London, 159, 83-94.

Edwards, M. (1986) Glacial environments. In: Sedimentary Environments and Facies (Ed. H.G. Reading), 2nd edn, pp. 445-469. Blackwell Science, Oxford.

Einsele, G. (2000) Sedimentary Basins. Evolution, Facies, and Sediment Budget. Springer, Berlin, 792 pp.

Fedonkin, M.A. (1992) Vendian faunas and the early evolution of metazoa. In: Origin and Early Evolution of the Metazoa (Eds J.H. Lipps and P.W. Signor), 1st edn, pp. 87-129. Plenum Press, New York.

Gaucher, C. (2000) Sedimentology, paleontology and stratigraphy of the Arroyo del Soldado Group (Vendian to Cambrian, Uruguay). Beringeria, 26, 1-120.

Gaucher, C. and Sprechmann, P. (1999) Upper Vendian skeletal fauna of the Arroyo del Soldado Group, Uruguay. Beringeria, 23, 55-91. 
Gaucher, C., Sprechmann, P. and Schipilov, A. (1996) Upper and Middle Proterozoic fossiliferous sedimentary sequences of the Nico Pérez Terrane of Uruguay: Lithostratigraphic units, paleontology, depositional environments and correlations. Neues Jb. Geol. Paläontol. Abh., 199, 339-367.

Gaucher, C., Sprechmann, P., Montaña, J. and Martínez, S. (1998) Litoestratigrafía, sedimentología y paleogeografía del Grupo Arroyo del Soldado (Vendiano-Cámbrico, Uruguay). In: II Congreso Uruguayo de Geología pp. 24-31. Montevideo, Actas.

Gaucher, C., Boggiani, P.C., Sprechmann, P., Sial, A.N. and Fairchild, T.R. (2003) Integrated correlation of the Vendian to Cambrian Arroyo del Soldado and Corumbá Groups (Uruguay and Brazil): palaeogeographic, palaeoclimatic and palaeobiologic implications. Precambrian Res., 120, 241278.

Gaucher, C., Sial, A.N., Blanco, G. and Sprechmann, P. (2004) Chemostratigraphy of the lower Arroyo del Soldado Group (Vendian, Uruguay) and palaeoclimatic implications. Gondwana Res., 7, 715-730.

Germs, G.J.B. (1972) New shelly fossils from Nama Group, South West Africa. Am. J. Sci., 272, 752-761.

Goñi, J.C. and Hoffstetter, R. (1964) Uruguay. In: Lexique stratigraphique international (Ed. R. Hoffstetter), Fascicule 9a, pp. 1-202. Centre National de la Recherche Scientifique, Paris.

Grotzinger, J.P., Bowring, S.A., Saylor, B.Z. and Kaufman, A.J. (1995) Biostratigraphic and geochronologic constraints on early animal evolution. Science, 270, 598-604.

Halverson, G.P., Hoffman, P.F., Schrag, D.P., Maloof, A.C. and Rice, A.H.N. (2005) Toward a Neoproterozoic composite carbon-isotope record. Geol. Soc. Am. Bull., 117, 11811207.

Harland, W.B. (1964) Critical evidence for a great infra-Cambrian glaciation. Geol. Rundsch., 54, 45-61.

Hartmann, L., Santos, O., Bossi, J., Campal, N., Schipilov A. and Mc Naughton, N.J. (2002) Zircon and Titanite U-Pb SHRIMP geochronology of Neoproterozoic felsic magmatism on the eastern border of the Rio de la Plata Craton, Uruguay. J. S. Am. Earth Sci., 15, 229-236.

Hoffman, P.F. and Schrag, D.P. (2000) Snowball Earth. Sci. Am., 282, 68-75.

Hoffman, P.F. and Schrag, D.P. (2002) The Snowball Earth hypothesis: testing the limits of global change. Terra Nova, 14, 129-155.

Hoffman, P.F., Kaufman, A.J. and Halverson, G.P. (1998a) Coming and goings of global glaciations on a neoproterozoic carbonate platform in Namibia. Geol. Today, 8, 1-9.

Hoffman, P.F., Kaufman, A.J., Halverson, G.P., and Schrag, D.P. (1998b) A Neoproterozoic Snowball Earth. Science, 281, 1342-1346.

Hoffmann, K.H., Condon, D.J., Bowring, S.A. and Crowley, J.L. (2004) A U-Pb zircon date from the Neoproterozoic Ghaub Formation, Namibia: constraints on Marinoan glaciation. Geology, 32, 817-820.

Hoffman, H.J. and Jackson, G.D. (1996) Notes on the geology and micropaleontology of the Proterozoic Thule Group, Ellesmere Island, Canada, and north-west Greenland. Geol. Surv. Can. Bull. 495, 1-26.

Hua, H., Chen, Z., Yuan, X., Zhang, L. and Xiao, S. (2005) Skeletogenesis and asexual reproduction in the earliest biomineralizing animal Cloudina. Geology, 33, 277-280.

Hyde, W.T., Crowley, T.J., Baum, S.K. and Peltier, W.R. (2000) Neoproterozoic "snowball earth" simulations with a coupled climate/ice-sheet model. Nature, 405, 425-429.
Jiang, G., Christie-Blick, N., Kaufman, A.J., Banerjee, D.M. and Rai, V. (2002) Sequence stratigraphy of the Neoproterozoic Infra Krol Formation and Krol Group, Lesser Himalaya, India. J. Sed. Res., 72, 524-542.

Jones, G. (1956) Memoria explicativa y mapa geológico de la región oriental del Departamento de Canelones, Boletín no. 34, pp. 193. Instituto Geológico del Uruguay, Montevideo.

Kappler, A., Pasquero, C., Konhauser, K.O. and Newman, D.K. (2005) Deposition of banded iron formations by anoxygenic photoprotphic Fe(II)-oxidizing bacteria. Geology, 33, 865-868.

Kirschvink, J.L. (1992) Late Proterozoic low-latitude global glaciation: the Snowball Earth. In: The Proterozoic Biosphere, A Multidisciplinary Study (Eds J.W. Schopf and C. Klein), 1st edn, pp. 51-52. Cambridge University Press, New York.

Klein, C. and Beukes, N.J. (1993) Sedimentology and geochemistry of the glaciogenic late Proterozoic Rapitan ironformation, in Canada. Econ. Geol., 80, 542-565.

Klein, C. and Ladeira, E.A. (2004) Geochemistry and mineralogy of Neoproterozoic banded iron-formations and some selected siliceous manganese formations from the Urucum district, Mato Grosso do Sul, Brazil. Econ. Geol., 99, 12331244.

Knoll, A.H. (1994) Proterozoic and Early Cambrian protists: evidence for accelerating evolutionary tempo. Proc. Natl Acad. Sci. USA, 91, 6743-6750.

Knoll, A.H. and Carroll, S.B. (1999) Early animal evolution: emerging views from comparative biology and geology. Science, 284, 2129-2137.

Knoll, A.H. and Sweet, K. (1985) Micropalaeontology of the Late Proterozoic Veteranen Group, Spitsbergen. Palaeontology, 28, 451-473.

Knoll, A.H. Walter, M.R., Narbonne, G.M. and Christie-Blick, N. (2004) A New Period for the geologic time scale. Science, 3005, 621-622.

Knoll, A.H. Walter, M.R., Narbonne, G.M. and Christie-Blick, N. (2006) The Ediacaran Period: a new addition to the geologic time scale. Lethaia, 39, 13-30.

Konhauser, K. (2006) Introduction to Geomicrobiology. Springer, Berlin, 425 pp.

Konhauser, K.O., Hamade, T., Raiswell, R., Morris, R.C., Ferris, F.G. and Canfield, D.E. (2002) Could bacteria have formed the Precambrian banded iron formations? Geology, 30, 1079-1082.

LaBerge, G.L., Robbins, E.I. and Han, T.M. (1987) A model for the biological precipitation of Precambrian iron-formations - geological evidence. In: Precambrian Iron-Formations (Eds P.W. Appel and G.L. LaBerge), 1st edn, pp. 69-96. Theophrastus, Athens.

Le Guerroué, E., Allen, P.A., Cozzi, A., Etienne, J.L. and Fanning, M. (2006) 50 Myr recovery from the largest negative $\delta^{13} \mathrm{C}$ excursion in the Ediacaran ocean. Terra Nova, 18, 147-153.

van Lith, Y., Warthmann, R., Vasconcelos, C. and McKenzie, J.A. (2003) Sulfate-reducing bacteria induce low temperature Ca-dolomite and high Mg-calcite formation. Geobiology, 1, 71-80.

Logan, B.W., Rezak, R. and Ginsburg, R. N. (1964) Classification and environmental significance of algal stromatolites. J. Geol., 72, 68-83.

Mansuy, C. and Vidal, G. (1983) Late Proterozoic Brioverian microfossils from France: taxonomic affinity and implications of plankton productivity. Nature, 302, 606-607.

Martin, M.W., Grazhdankin, D.V., Bowring, S.A., Evans, D.A.D., Fedonkin, M.A. and Kirschvink, J.L. (2000) Age of 
Neoproterozoic bilatarian body and trace fossils, White Sea, Russia: implications for metazoan evolution. Science, 288, 841-845.

Masquelin, H. (1990) Análisis estructural de las zonas de cizalla en las migmatitas de Punta del Este - Uruguay. Acta Geol. Leopoldensia, 30, 139-158.

Masquelin, H. and Sánchez, L. (1993) Propuesta de evolución tectono-sedimentaria para la fosa tardi-brasiliana en la región de Piriápolis, Uruguay. Rev. Brasil. Geocienc., 23, 313322.

Midot, D. (1984) Etude geologique et diagnostic metallogénique pour l'exploration du secteur de Minas (Uruguay). Diplome de Docteur de 3e Cycle. Universitè Pierre et Marie Curie, Paris.

Moczydlowska M. (2005) Taxonomic review of some Ediacarian acritarchs from the Siberian Platform. Precambrian Res., 136, 283-307.

Montaña, J. and Sprechmann, P. (1993) Calizas estromatolíticas y oolíticas y definición de la Formación Arroyo de la Pedrera (?Vendiano, Uruguay). Rev. Brasil. Geocienc., 23, 306-312.

Murphy, M.A and Salvador, A. (1999) International stratigraphic guide - an abridged version. Episodes, 22, 255-271.

Narbonne, G.M. (2005) The Ediacara biota: Neoproterozoic origin of animals and their ecosystems. Annu. Rev. Earth Planet. Sci., 33, 421-442.

Oyhantçabal P. (2005). The Sierra Ballena Shear zone: kinematics, timing and its significance for the geotectonic evolution of southeast Uruguay. PhD Thesis, Georg-AugustUniversität Göttingen, Göttingen, 147 pp.

Oyhantçabal, P., Derregibus, M. and De Souza, S. (1993) Geología do extremo sul da Formaçao Sierra de Ánimas (Uruguay). In: $V$ Simposio Sul-Brasileiro de Geología, Curitiba, Brazil. Boletín de Resumos, 1, 4-5.

Oyhantçabal, P. Heimann, A. and Miranda, S. (2001). An evaluation of strain in the syntectonic Solis de Mataojo Granitic Complex, Uruguay. J. Struct. Geol., 23, 807-817.

Pazos, P., Sánchez Bettucci, L. and Tófalo, R. (1998) Procesos sedimentarios e indicadores paleoclimáticos en la sección inferior de la Formación Playa Hermosa, Cuenca Playa Verde, Piriápolis, Uruguay. In: II Congreso Uruguayo de Geología, Actas, pp. 64-69.

Pazos P., Tófalo, R. and Sánchez Bettucci, L. (2003) The record of the Varanger Glaciation at the Rio de la Plata Craton, Vendian-Cambian of Uruguay. Gondw. Res., 6, 65-77.

Pecoits, E. (2002) Análisis faciológico y aspectos geológicos de la Formación Las Ventanas; un nuevo enfoque. In: II Taller Sobre la Estratigrafía del Precámbrico del Uruguay (Eds E. Pecoits and H. Masquelin), pp. 34-36. Facultad de Ciencias, Montevideo.

Pecoits E. (2003a) Sedimentología y consideraciones estratigráficas de la Formación Las Ventanas en su área tipo, departamento de Maldonado, Uruguay. In: Estratigrafía del Precámbrico del Uruguay (Ed. E. Pecoits), Rev. Soc. Uruguay. Geol. Spec. Publ., 1, 124-140.

Pecoits, E. (2003b) Age and preliminary correlation of the Las Ventanas Formation and Bom Jardim-Cerro do Bugio allogroups (Vendian, Uruguay and Brazil). In: III International Colloquium Vendian-Cambrian of W-Gondwana. (Ed. H.E. Frimmel), Programme and Extended Abstracts, pp. 32-34.

Pecoits, E. and Oyhantçabal, P. (2004) Geotectonic evolution of Uruguay during the Neoproterozoic-Cambrian. In: 1st Symposium on Neoproterozoic-Early Paleozoic events in SW-Gondwana. Extended Abstracts, IGCP Project 478, Second Meeting, pp. 43-45, Brazil.
Pecoits, E., Aubet, N., and Sánchez Bettucci, L. (2004a) Sedimentología, estratigrafía y paleontología de la Formación Las Ventanas (Vendiano inferior, Uruguay). In: X Reunion Argentina de Sedimentología pp. 134-135.

Pecoits, E., Aubet, N., and Sánchez Bettucci, L. (2004b) Uruguayan Neoproterozoic banded iron formations (BIF) and its tectonic setting. In: X Reunion Argentina de Sedimentología pp. 132-134, San Luis.

Pecoits, E., Aubet, N., Oyhantçabal, P. and Sánchez Bettucci, L. (2005a) Estratigrafía de sucesiones sedimentarias y volcanosedimentarias Neoproterozoicas del Uruguay. Rev. Soc. Uruguay. Geol., 11, 18-27.

Pecoits, E., Aubet, N., and Sánchez Bettucci, L. (2005b) Estratigrafía de la Formación Las Ventanas y su correlación con los alogrupos Bom Jardim y Cerro do Bugio (Vendiano, Uruguay y Brasil). In: XII Congreso Latinoamericano de Geología Resúmenes Extendidos, Actas Cd, Quito.

Preciozzi, F. and Fay, A. (1988) Carta geológica del Uruguay, Hoja F-23 Pirarajá, Escala 1:100·000. Memoria explicativa. DINAMIGE-UdelaR, Montevideo, $15 \mathrm{pp}$.

Preciozzi, F., Spoturno, J., Heinzen, W. and Rossi, P. (1988) Carta Geológica del Uruguay a escala 1:500·000. Memoria explicativa. DINAMIGE, Montevideo, $90 \mathrm{pp}$.

Preciozzi, F., Pena, S., Masquelin, E., Pias, J. and Tabo, F. (1989) Memoria explicativa del fotoplano Piriápolis. DI.NA.MI.GE. - Fac. de Agronomía - Fac. de Hum. y Ciencias, Montevideo, $11 \mathrm{pp}$.

Preciozzi, F., Masquelin, H. and Sánchez Bettucci, L. (1993) Geología de la Porción Sur del Cinturón Cuchilla de Dionisio (I Simp. Int. Neoproterozoico - Cámbrico de La Cuenca del Plata), pp. 1-39. Guía de Excursiones, La Paloma.

Rivalenti, G., Mazzucchelli, M., Molesini, M., Petrini, R., Girardi, V.A.V., Bossi, J. and Campal, N. (1995) Petrology of Late Proterozoic mafic dykes in the Nico Perez region, Central Uruguay. Mineral. Petrol., 55, 239-263.

Sánchez, L. (1998) Evolución tectónica del Cinturon Dom Feliciano en la región Minas-Piriápolis, Uruguay. Unpublished $\mathrm{PhD}$ thesis, Univ. de Buenos Aires, Buenos Aires.

Sánchez, L. and Linares, E. (1996) Primeras edades en basaltos del Complejo Sierra de las Ánimas, Uruguay. In: XIII Congreso Geológico Argentino y III Congreso de Exploración de Hidrocarburos Actas I, pp. 399-404.

Sánchez, L. and Rapalini, A.E. (2002) Paleomagnetism of the Sierra de Las Animas Complex, southern Uruguay: its implications in the assembly of western Gondwana. Precambrian Res., 118, 243-265.

Saylor, B.Z., Kaufman, A.J., Grotzinger, J.P. and Urban, F. (1998) A composite reference section for terminal Proterozoic strata of southern Namibia. J. Sed. Res., 68, 1223-1235.

Schopf, J.W. (1991) Collapse of the Late Proterozoic ecosystem. S. Afr. J. Geol., 94, 33-43.

Seilacher, A. (1996) Explosive evolution in the Precambrian/ Cambrian transition. In: Evolución: aspectos interdisciplinarios (Ed. E. Molina), Vol. 6. pp. 65-78. Universidad de Zaragoza, Zaragoza.

Shields, G.A. (2005) Cap carbonates: a critical appraisal of existing formation models and the Plumeworld hypothesis. Terra Nova, 17, 299-310.

Sprechmann, P., Gaucher, C., Blanco, G. and Montaña, J. (2004) Stromatolitic and trace fossils community of the Cerro Victoria Formation, Arroyo del Soldado Group (Lowermost Cambrian, Uruguay). Gondwana Res., 7, 753766.

Thompson, M.D., and Bowring, S.A. (2000) Age of the Squantum 'tillite,' Boston basin, Massachusetts: U-Pb 
zircon constraints on terminal Neoproterozoic glaciation. Am. J. Sci., 300, 630-655.

Umpierre, M. and Halpern, M. (1971) Edades Sr-Rb del Sur de la República Oriental del Uruguay. Rev. Asoc. Geol. Argentina, 26, 133-155.

Vail, P.R., Mitchum, R.M., and Thompson, S. (1977) Global cycles of relative changes of sea level. In: Seismic Stratigraphy - Applications to Hydrocarbon Exploration (Ed. C.E. Payton), AAPG Mem., 27, 83-98.

Valentine, J.W. (2004) On the Origin of Phyla. The University of Chicago Press, Chicago, $614 \mathrm{pp}$.

Vasconcelos, C. and McKenzie, J.A. (1997) Microbial mediation of modern dolomite precipitation and diagenesis under anoxic conditions (Lagoa Vermelha, Rio de Janeiro, Brazil). J. Sed. Res., 67, 378-390.

Vasconcelos, C., Warthmann, R., McKenzie, J.A., Visscher, P.T., Bittermann, A.G. and van Lith, Y. (2006) Lithifying microbial mats in Lagoa Vermelha, Brazil: modern Precambrian relics? Sed. Geol., 185, 175-183.

Vidal, G. (1976) Late Precambrian microfossils from the Visingsö Beds in southern Sweden. Fossils Strata, 9, 1-57.

Vidal, G. and Knoll, A.H. (1982) Radiations and extinctions of plankton in the late Proterozoic and early Cambrian. Nature, 297, 57-60.

Vidal, G. and Moczydlowska-Vidal, M. (1997) Biodiversity, speciation, and extinction trends of Proterozoic and Cambrian Phytoplankton. Paleobiology, 23, 230-246.

Walter, M.R. and Hofmann, H.J. (1983) The paleontology and paleoecology of Precambrian iron-formations. In: Iron-Formation: Facts and Problems (Eds A.F. Trendall and R.C. Morris), 1st edn, pp. 373-400. Elsevier, Amsterdam.
Walter, M.R., Veevers, J.J., Calver, C.R., Gorjan, P. and Hill, A.C. (2000) Dating the 840-544 Ma Neoproterozoic interval by isotopes of Strontium, Carbon, and Sulphur in seawater, and some interpretative models. Precambrian Res., 100, 371-433.

Wang, Z., Yin, C., Gao, L. and Liu, Y. (2002) Chemostratigraphic characteristics and correlation of the Sinian stratotype in the eastern Yangtze Gorges area, Yichang, Hubei Province. Geol. Rev., 48, 408-415.

Warthmann, R., van Lith, Y., Vasconcelos, C. and McKenzie, J.A. (2000) Bacterially induced dolomite precipitation in anoxic culture experiments. Geology, 28, 1091-1094.

Xiao, S., Zhang, Y. and Knoll, A.H. (1998) Three-dimensional preservation of algae and animal embryos in a Neoproterozoic phosphorite. Nature, 391, 553-558.

Xiao, S., Bao, H., Wang, H., Kaufman, A.J., Zhou, Ch., Li, G., Yuan, X. and Ling, H. (2004) The Neoproterozoic Quruqtagh Group in eastern Chinese Tianshan: evidence for a postMarinoan glaciation. Precambrian Res., 130, 1-26.

Young, G.M. (2002) Stratigraphic and tectonic settings of Proterozoic glaciogenic rocks and banded iron-formations: relevance to the Snowball Earth debate. J. Afr. Earth Sci., 35, 451-466.

Zhou, C., Chen, Z. and Xue, Y. (2002) New microfossils from the late Neoproterozoic Doushantuo Formation at Chaoyang phosphorite deposit in Jiangxi Province, South China. Acta Palaeontol. Sinica, 41, 178-192.

Manuscript received 28 April 2006; revision accepted 18 September 2007 